\title{
Methodology and Technical Input for the 2021 Review and Revision of the U.S. Critical Minerals List
}

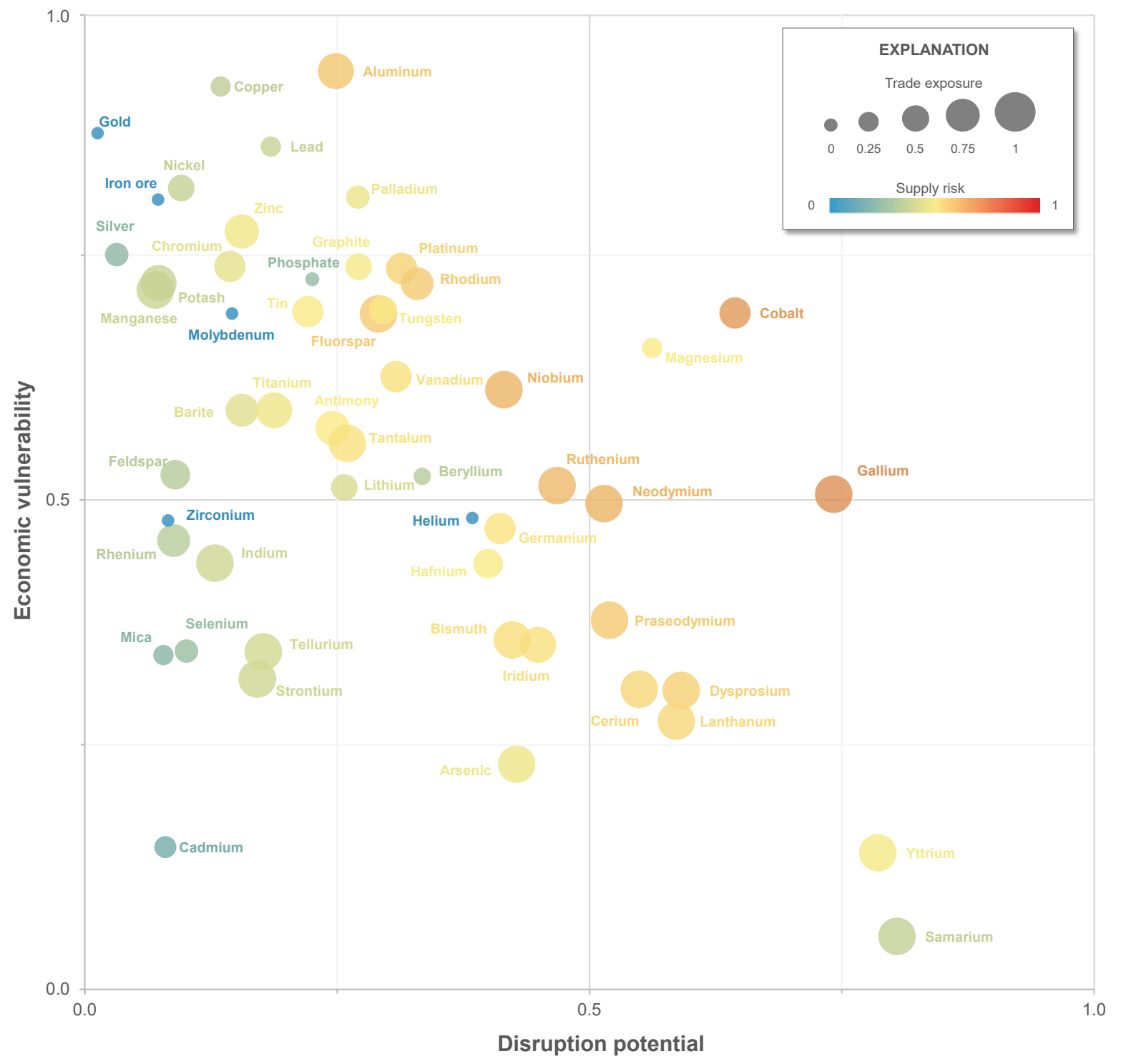

Open-File Report 2021-1045 
Cover. Graph showing the results of calculations made to determine the supply risk for various mineral commodities in 2018. The methodology in this report describes how these three components-disruption potential (horizontal axis), economic vulnerability (vertical axis), trade exposure (point size) — and overall supply risk (point shade) are being evaluated to come up with recommendations for what mineral commodities should be considered for inclusion on the U.S. Critical Minerals List. 


\section{Methodology and Technical Input for the 2021 Review and Revision of the U.S. Critical Minerals List}

By Nedal T. Nassar and Steven M. Fortier

Open-File Report 2021-1045 


\section{U.S. Geological Survey, Reston, Virginia: 2021}

For more information on the USGS - the Federal source for science about the Earth, its natural and living resources, natural hazards, and the environment-visit https://www.usgs.gov or call 1-888-ASK-USGS.

For an overview of USGS information products, including maps, imagery, and publications, visit https://store.usgs.gov/.

Any use of trade, firm, or product names is for descriptive purposes only and does not imply endorsement by the U.S. Government.

Although this information product, for the most part, is in the public domain, it also may contain copyrighted materials as noted in the text. Permission to reproduce copyrighted items must be secured from the copyright owner.

Suggested citation:

Nassar, N.T., and Fortier, S.M., 2021, Methodology and technical input for the 2021 review and revision of the U.S. Critical Minerals List: U.S. Geological Survey Open-File Report 2021-1045, 31 p., https://doi.org/10.3133/ ofr20211045.

ISSN 2331-1258 (online) 


\section{Acknowledgments}

The authors would like to acknowledge the valuable input and feedback of the entire staff of the U.S. Geological Survey National Minerals Information Center, with special thanks to J.L. Brainard, J. Gambogi, G. Matos, M.E. McRae, R.F. Schulte, A.C. Tolcin, and C.C. Tuck. The authors would also like to acknowledge the members of the Working Group of the National Science and Technology Council Critical Minerals Subcommittee-D. Bauer (U.S. Department of Energy), J. Darden (U.S. Department of Homeland Security), D. Gage (U.S. Department of State), M. Hendrix (U.S. Department of Homeland Security), D. Keavney (U.S. Department of State), A. Lewis (U.S. Department of State), D. Pineault (U.S. Department of Defense), and S. Stevens (U.S. Department of Homeland Security)—for their input and feedback through the deliberation and review process. 



\section{Contents}

Acknowledgments .........................................................................................................................ii

Summary of the Methodology and Recommendations for Updating the Critical Minerals List.......1

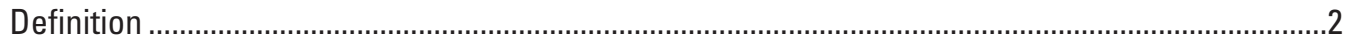

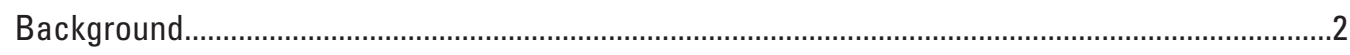

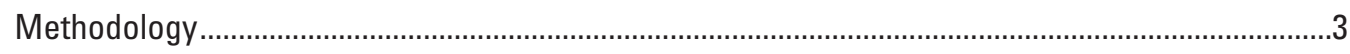

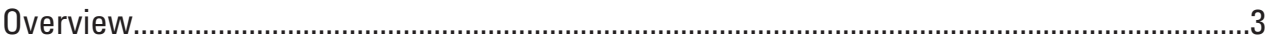

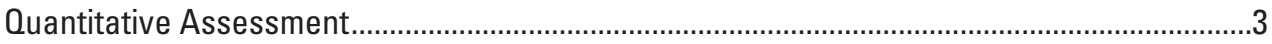

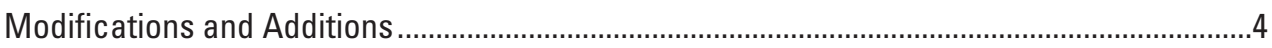

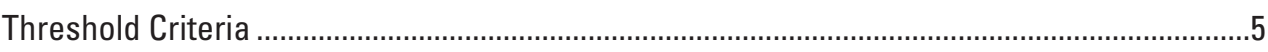

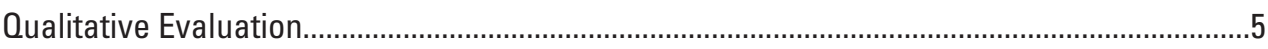

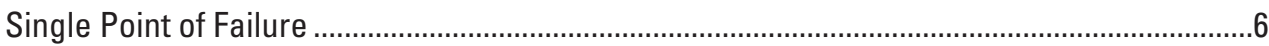

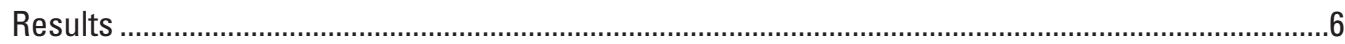

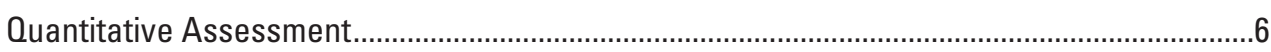

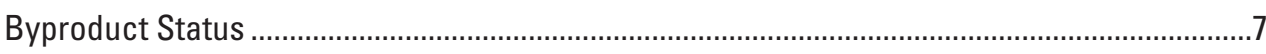

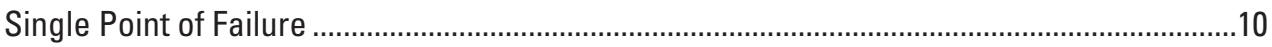

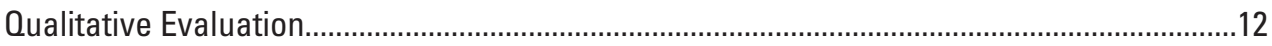

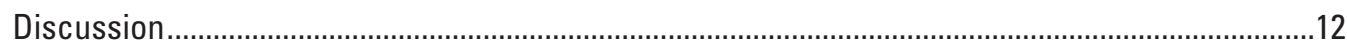

Comparison to the Initial Critical Minerals List................................................................12

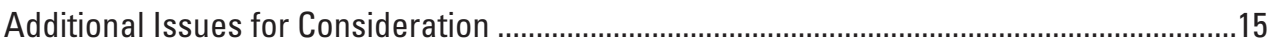

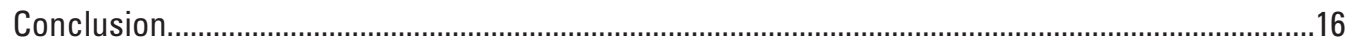

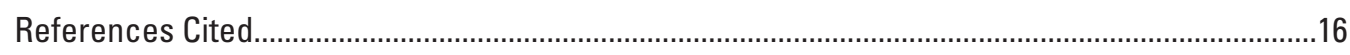

Appendix 1. Modifications and Additions to the Assessment ....................................................19

\section{Figures}

1. Supply risk indicators for selected mineral commodities from 2007 through 2018 ..........8

2. Assessment of mineral commodity supply risk ............................................................10

3. Heat map displaying the supply risk for all mineral commodities examined for

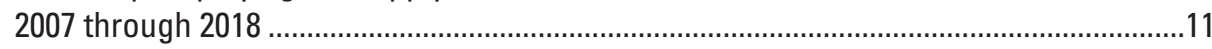

\section{Tables}

1. Threshold criteria for each supply risk component..........................................................

2. Overview of mineral commodity assessment, ranking, and categorization for inclusion on the Critical Minerals List in 2021 


\section{Conversion Factors}

U.S. customary units to International System of Units

\begin{tabular}{llll}
\hline \multicolumn{1}{c}{ Multiply } & \multicolumn{1}{c}{ By } & To obtain \\
\hline \multicolumn{3}{c}{ Mass } \\
ounce, avoirdupois $(\mathrm{oz})$ & 28.35 & gram $(\mathrm{g})$ & \\
pound, avoirdupois $(\mathrm{lb})$ & 0.4536 & kilogram $(\mathrm{kg})$ & metric ton $(\mathrm{t})$ \\
ton, short $(2,000 \mathrm{lb})$ & 0.9072 & metric ton $(\mathrm{t})$ & \\
ton, long $(2,240 \mathrm{lb})$ & 1.016 & & \\
\hline
\end{tabular}

International System of Units to U.S. customary units

\begin{tabular}{|c|c|c|}
\hline Multiply & By & To obtain \\
\hline \multicolumn{3}{|c|}{ Mass } \\
\hline gram $(\mathrm{g})$ & 0.03527 & ounce, avoirdupois (oz) \\
\hline kilogram (kg) & 2.205 & pound avoirdupois (lb) \\
\hline metric ton $(\mathrm{t})$ & 1.102 & ton, short $[2,000 \mathrm{lb}]$ \\
\hline metric ton $(\mathrm{t})$ & 0.9842 & ton, long $[2,240 \mathrm{lb}]$ \\
\hline
\end{tabular}

Temperature in Kelvin can be converted to Celsius $\left({ }^{\circ} \mathrm{C}\right)$ by subtracting 273.15 , and Celsius $\left({ }^{\circ} \mathrm{C}\right)$ may be converted to degrees Fahrenheit $\left({ }^{\circ} \mathrm{F}\right)$ as follows: ${ }^{\circ} \mathrm{F}=\left(1.8 \times{ }^{\circ} \mathrm{C}\right)+32$ 


\section{Abbreviations}

$\begin{array}{ll}\text { ASI } & \text { ability to supply index } \\ \text { CML } & \text { Critical Minerals List } \\ \text { CMS } & \text { Critical Minerals Subcommittee } \\ \text { COVID-19 } & \text { coronavirus disease 2019 } \\ \text { HS } & \text { Harmonized System } \\ \text { HTS } & \text { Harmonized Tariff Schedule } \\ \text { NAICS } & \text { North American Industry Classification System } \\ \text { NSTC } & \text { National Science and Technology Council } \\ \text { PGM } & \text { platinum-group metal } \\ \text { REC } & \text { rare earth compound } \\ \text { REE } & \text { rare earth element } \\ \text { SEG+ } & \text { samarium, europium, gadolinium, and a mix of heavy rare earth elements } \\ \text { SPOF } & \text { single point of failure } \\ \text { TREO } & \text { total rare earth oxide } \\ \text { U.S. } & \text { United States } \\ \text { U.S.C. } & \text { United States Code } \\ \text { WSI } & \text { willingness to supply index } \\ \text { ZOC } & \text { zirconium oxychloride }\end{array}$




\section{Periodic Table of the Elements}

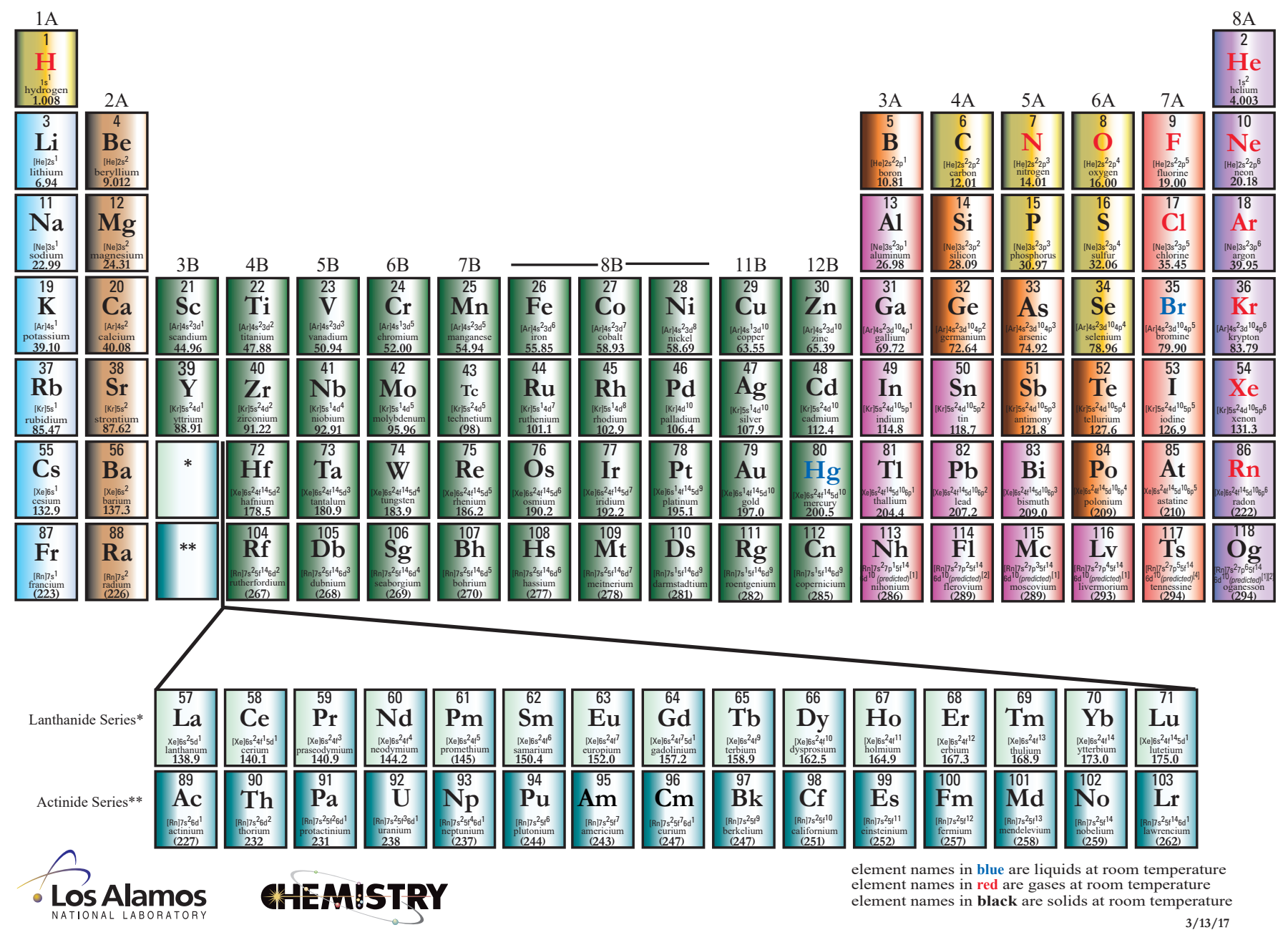

Modified from Los Alamos National Laboratory Chemistry Division; available at https://periodic.lanl.gov/images/periodictable-313-17.pdf 


\title{
Methodology and Technical Input for the 2021 Review and Revision of the U.S. Critical Minerals List
}

\author{
By Nedal T. Nassar and Steven M. Fortier
}

Pursuant to Section 7002 ("Mineral Security") of

Title VII ("Critical Minerals") of the Energy Act of 2020

(Public Law 116-260, December 27, 2020, 116th Cong.), the

Secretary of the Interior, acting through the Director of the U.S. Geological Survey, is tasked with reviewing and revising the methodology used to evaluate mineral criticality and the U.S. Critical Minerals List (CML) no less than every 3 years. The initial CML was published in the Federal Register on May 18, 2018 (U.S. Department of the Interior, 2018), in response to Executive Order No. 13817, A Federal Strategy to Ensure Secure and Reliable Supplies of Critical Minerals (3 CFR, 2017 Comp, p. 397-399). This report documents the updated evaluation methodology and the resultant updated draft list of minerals recommended for inclusion in the CML.

\section{Summary of the Methodology and Recommendations for Updating the Critical Minerals List}

The methodology for identifying nonfuel mineral commodities as "critical" involved a quantitative assessment based on a risk modeling framework in which commodities with the greatest supply risk were those whose (1) global production was concentrated in countries that may become unable or unwilling to continue to supply to the United States; (2) U.S. consumption was predominately dependent on foreign supplies; and (3) U.S. consumption represented a large expenditure for U.S. manufacturing industries with low profitability but who contributed greatly to the U.S. economy. This quantitative assessment was based on a recently published approach for assessing the supply risk to the U.S. manufacturing sector and represents an enhancement of the original metrics used to generate the initial CML (Nassar and others, 2020b). A quantitative threshold based on objective criteria was also established to identify which commodities should be recommended for inclusion on the CML. Commodities for which the necessary data to perform the quantitative assessment were not available were assessed qualitatively based on available information.
In addition to the quantitative assessment, which focused on potential foreign supply disruptions, an evaluation of domestic supplies was also performed. Specifically, mineral commodities that have a single domestic producer along their raw material supply chains were identified as having a single point of failure (SPOF) and were automatically recommended for inclusion on the CML.

A total of 54 mineral commodities had sufficient data to be analyzed using the quantitative assessment. These $54 \mathrm{~min}$ eral commodities included 7 individual rare earth elements (REEs) and 5 platinum-group metals (PGMs), which were analyzed as groups in the initial CML. Pursuant to the Energy of Act of 2020 (Public Law 116-260), water; common varieties of industrial minerals, such as sand, gravel, stone, pumice, cinders, and clay; and fuel minerals, including uranium, were explicitly excluded from consideration in this analysis.

Of the 54 mineral commodities analyzed using the quantitative assessment, 36 met the quantitative threshold criteria. In rank order from highest to lowest based on a recency-weighted mean of their overall supply risk scores, these commodities were the following: gallium, niobium, cobalt, neodymium, ruthenium, rhodium, dysprosium, aluminum, fluorspar, platinum, iridium, praseodymium, cerium, lanthanum, bismuth, yttrium, antimony, tantalum, hafnium, tungsten, vanadium, tin, magnesium, germanium, palladium, titanium, zinc, graphite, chromium, arsenic, barite, indium, samarium, manganese, lithium, and tellurium. An additional three commodities are also recommended for inclusion on the updated draft CML based on the SPOF criteria: beryllium, nickel, and zirconium. Three commodities on the initial CML, cesium, rubidium, scandium, as well as the other REEs (listed in ascending order of atomic number-europium, gadolinium, terbium, holmium, erbium, thulium, ytterbium, and lutetium) were not evaluated using the quantitative method because of insufficient data. Based on a qualitative evaluation of their supply and demand, none of these mineral commodities are recommended for removal from the updated draft CML. Overall, of the commodities evaluated, two commodities not on the initial CML are recommended for inclusion on the updated draft CML (nickel and zinc) and four on the initial CML (helium, potash, rhenium, and strontium) did not meet either the quantitative assessment or the SPOF criteria. The 
latter are subject to further discussion through the interagency process for a decision of whether or not they should be included. Future iterations of this analysis may enhance the quantitative assessment and include additional mineral commodities as data become available to continue to improve and expand the evaluation.

\section{Definition}

The Energy Act of 2020 defines "critical minerals" as the minerals, elements, substances, or materials that "(i) are essential to the economic or national security of the United States; (ii) the supply chain of which is vulnerable to disruptions (including restrictions associated with foreign political risk, abrupt demand growth, military conflict, violent unrest, anti-competitive or protectionist behaviors, and other risks throughout the supply chain); and (iii) serve an essential function in the manufacturing of a product (including energy technology-, defense-, currency-, agriculture-, consumer electronics-, and healthcare-related applications), the absence of which would have significant consequences for the economic or national security of the United States" (Public Law 116-260, section 7002(c)(4)(A)).

The Energy Act of 2020 (Public Law 116-260) further specifies that the term "critical minerals" does not include "(i) fuel minerals, (ii) water, ice, or snow; (iii) common varieties of sand, gravel, stone, pumice, cinders, and clay." Uranium is formally defined as a fuel mineral under The Mining and Minerals Policy Act of 1970 (30 U.S.C. 21(a)). The uranium mining and processing supply chain has been evaluated extensively elsewhere (U.S. Department of Energy, 2020) and issues regarding the availability and reliability of nuclear fuel are addressed in a separate section of the Energy Act of 2020 (Public Law 116-260, Title II, "Nuclear").

The mineral commodities recommended here for inclusion on the updated draft CML are not intended to replace related terms and definitions of materials that are deemed strategic, critical, or otherwise important by other Federal agencies (for example, the National Defense Stockpile).

\section{Background}

A convergence of factors and trends, including increased global production concentration, greater dependency on foreign supplies, and limited end-of-life recycling, has elevated the risk of a supply disruption of the nonfuel mineral commodities that are essential for both established and emerging technologies that enable modern society (Nassar and others, 2020a). Recent events, including trade disputes, resource nationalism, and the global coronavirus disease 2019 (COVID-19) pandemic further highlight the risk of disruptions to the U.S. economy and national security (Jowitt, 2020; Nassar and Fortier, 2020).
Investigations into raw material supply security have been undertaken for and by the U.S. Federal Government for more than a century (National Research Council, 2008). During the past decade, the National Science and Technology Council's (NSTC's) Critical Minerals Subcommittee (CMS) within the Office of Science and Technology Policy in the Executive Office of the President has provided advice and assistance on policies, procedures, and plans relating to the identification and review of critical mineral supply chains and the facilitation of interagency cooperation and coordination on actions aimed at minimizing the risk to the United States (National Science and Technology Council, 2016; U.S. Department of Commerce, 2019).

Pursuant to Executive Order No. 13817, A Federal Strategy to Ensure Secure and Reliable Supplies of Critical Minerals, the Secretary of the Interior, in coordination with the Secretary of Defense and in consultation with the heads of other relevant executive departments and agencies, was tasked with developing and submitting a draft list of critical minerals to the Federal Register. As part of that response, the U.S. Geological Survey provided a technical input document that recommended the inclusion of 33 individual mineral commodities and 2 mineral commodity groups - the PGMs and the REEs - on the Critical Minerals List (CML) (Fortier and others, 2018). After careful review and consideration of more than 450 public comments, the U.S. Department of the Interior (2018) finalized this initial list in the Federal Register.

In coordination with the member agencies of the NSTC CMS, the U.S. Department of Commerce released a Federal strategy report that outlined six Calls to Actions, 24 goals, and 61 recommendations that identified specific steps that the Federal Government can take to achieve the objectives outlined in Executive Order No. 13817 (U.S. Department of Commerce, 2019). Under Call to Action 4, "Improve Understanding of Domestic Critical Mineral Resources," the report recommended that the CML be reviewed every 2 years and updated when necessary. Call to Action 4 also recommended the categorization and prioritization of the mineral commodities on the CML to enable commodity-specific mitigation strategies (U.S. Department of Commerce, 2019). As part of Executive Order No. 13953 of September 30, 2020 (Daily Comp. Pres. Docs., 2020 DCPD No. 202000746, p. 1-6), Addressing the Threat to the Domestic Supply Chain From Reliance on Critical Minerals From Foreign Adversaries and Supporting the Domestic Mining and Processing Industries, Executive Order No. 13817 was amended to add the requirement that the CML be updated periodically to reflect current data and policy priorities. Similarly, Section 7002(c), titled "Critical Mineral Designations," of the Energy Act of 2020 (Public Law 116-260) requires the Secretary of the Interior, acting through the Director of the U.S. Geological Survey, to publish a description of the draft methodology and the resultant draft list of minerals that qualify as critical - including the identification of those that are found principally as byproducts - in the Federal Register for public comment. No later than 45 days after posting the 
draft documents to the Federal Register, the methodology and updated CML are to be published in final form in the Federal Register. Section 7002(c) also requires that the list be reviewed and updated at least every 3 years.

The purpose of this report is to provide the technical input and recommendations for updating and prioritizing the CML pursuant to the requirements of the associated Executive orders and the Energy Act of 2020 (Public Law 116-260). This effort has been coordinated through a working group within the NSTC CMS in which representatives from multiple Federal agencies, including the Departments of Defense, Energy, Homeland Security, and State, participated in discussion and deliberations regarding the approach presented here.

\section{Methodology}

\section{Overview}

The methodology used to develop the initial CML used two quantitative indicators (country-level production concentration and U.S. net import reliance) and a qualitative assessment of importance (Fortier and others, 2018). The methodology used here was based on the approach developed by Nassar and others (2020b), which defines supply risk as the confluence of the following three factors: the likelihood of a foreign supply disruption, the dependency of the U.S. manufacturing sector on foreign supplies, and the vulnerability of the U.S. manufacturing sector to a supply disruption. In effect, the approach developed by Nassar and others (2020b) was an enhancement of the methodology used to develop the initial CML. Specifically, the enhanced methodology retains the net import reliance indicator, enhances the production concentration indicator by focusing on production concentration outside of the United States and weighting each producing country's production contribution by its ability or willingness to continue to supply the United States, and converts the qualitative assessment of importance into a quantitative assessment of economic vulnerability for the U.S. manufacturing sector. The underlying rationale and the specific approach, data sources, and assumptions used to calculate each component are described in detail by Nassar and others (2020b) and briefly below.

\section{Quantitative Assessment}

Supply risk, as a score ranging from 0 (low) to 1 (high), was calculated as the geometric mean of three components, as follows:

$$
S R_{i, t}=\sqrt[3]{D P_{i, t} \cdot T E_{i, t} \cdot E V_{i, t}},
$$

where, for commodity $i$ and year $t$,

$$
S R \quad \text { is the supply risk; }
$$

$D P \quad$ is the disruption potential;

$T E \quad$ is the trade exposure; and

$E V \quad$ is the economic vulnerability.

These variables represent the three components of the risk, respectively: hazard, exposure, and vulnerability (Crichton, 1999).

The disruption potential was calculated as the sum of the squares of each producing country's share of global production (excluding that of the United States), weighted by each producing country's willingness or ability to continue to supply, as follows:

$$
D P_{i, t}^{r a w}=\sum_{c}\left(P S_{i, t, c}^{2} \cdot \max \left(A S I_{t, c}, W S I_{t, c}\right)\right)
$$

where, for commodity $i$, year $t$, and country $c$,

$D P \quad$ is that country's disruption potential;

$P S \quad$ is that country's share of global production for that commodity;

$A S I \quad$ is that country's ability to supply index; and

WSI is that country's willingness to supply index.

The ASI is based on the Fraser Institute's policy perception index, which assesses producing countries' political stability, security, availability of labor, adequacy of infrastructure, trade barriers, regulations, taxation, uncertainties regarding protected areas and disputed land claims, and other factors that can affect a jurisdiction's attractiveness for mining activities (Stedman and others, 2020). The WSI assesses the trade, ideological, and defense ties that a producing country has with the United States to provide a proxy for the likelihood that it may deliberately disrupt its supplies to U.S. manufacturers. Details for both indexes are provided by Nassar and others (2020b).

Note that this evaluation of disruption potential includes a minor modification to the one used by Nassar and others (2020b) in that the square of the production shares is weighted by the ASI or the WSI (whichever is greater) rather than by both the ASI and the WSI. This is done to reflect that supply disruptions may occur if a producing country is either unable or unwilling (rather than being both unable and unwilling) to continue to supply the United States.

The calculated (or raw) disruption potential scores for each commodity for each year were normalized to a common 0-to- 1 scale based on the observed minimum and maximum scores across all commodities and all years, as follows:

$$
D P_{i, t}=\frac{D P_{i, t}^{\text {raw }}-D P_{\text {min }}}{D P_{\text {max }}-D P_{\text {min }}}
$$

Trade exposure is based on net import reliance (as a percent of apparent consumption) of the United States, a metric that has been developed and updated annually by the U.S. Geological Survey for decades (Fortier and others, 2015). It was calculated as follows: 


$$
T E_{i, t}=\frac{I_{i, t}-E_{i, t}+\Delta S_{i, t}}{A C_{i, t}}
$$

where, for commodity $i$ in year $t$,

$T E \quad$ is the trade exposure;

$I \quad$ is the total U.S. imports of the applicable

Harmonized Tariff Schedule (HTS) trade codes;

$E \quad$ is the total U.S. exports of the applicable HTS trade codes;

$\Delta S \quad$ is the changes in U.S. industry and government stocks; and

$A C \quad$ is the U.S. apparent consumption.

Apparent consumption was calculated as follows:

$$
A C_{i, t}=P P_{i, t}+S P_{i, t}+I_{i, t}-E_{i, t}+\Delta S_{i, t},
$$

\begin{tabular}{|c|c|}
\hline & \\
\hline$P I$ & Inited States \\
\hline$S P$ & $\begin{array}{l}\text { is the secondary (old scrap) production of the } \\
\text { United States; }\end{array}$ \\
\hline$I$ & $\begin{array}{l}\text { is the total U.S. imports of the applicable } \\
\text { Harmonized Tariff Schedule (HTS) } \\
\text { trade codes; }\end{array}$ \\
\hline$E$ & $\begin{array}{l}\text { is the total U.S. exports of the applicable HTS } \\
\text { trade codes; and }\end{array}$ \\
\hline$\Delta S$ & $\begin{array}{l}\text { is the changes in U.S. industry and } \\
\text { Government stocks. }\end{array}$ \\
\hline
\end{tabular}

where, for commodity $i$ in year $t$,

All variables used to calculate trade exposure and apparent consumption were based on mass quantities adjusted for the content of the associated mineral commodity. Trade exposure thus assesses the degree to which U.S. consumption is based on foreign sources. It is limited to the range from 0 for commodities for which the United States was a net exporter to 1 for commodities for which the United States was entirely dependent on foreign sources for its consumption.

To calculate economic vulnerability, each mineral commodity's uses were linked to a set of manufacturing industries, as defined by the North American Industry Classification System (NAICS), that consumed that commodity. Commodities for which expenditures were high in industries with low operating profits but that contributed greatly to the U.S. economy were given higher economic vulnerability scores, as follows:

$$
E V_{i, t}^{r a w}=\sum_{j}\left(\frac{V A_{t, j}}{G D P_{t}} \cdot \frac{E X P_{i, t, j}}{O P_{t, j}}\right),
$$

where, for commodity $i$, year $t$, and industry $j$, $E V \quad$ is the economic vulnerability;
$V A$ is the industry's value added - that is, its contribution to the U.S. gross domestic product $(G D P)$;

EXP is the industry's expenditure on that commodity; and

$O P \quad$ is the industry's operating profit.

The expenditures to operating profits ratio provides a measure of each industry's vulnerability to the mineral commodity, whereas the ratio of value added to the gross domestic product provides a measure of that industry's economic importance to the overall economy. The rationale behind the economic vulnerability components stems from the idea that industries with limited profits and greater expenditure on a commodity have less flexibility to deal with a supply disruption than industries with healthy profits and minimal expenditures.

Raw economic vulnerability scores were also normalized to range from 0 to 1 , with higher scores indicating greater vulnerability, based on the observed minimum and maximum scores across all commodities and years, as follows:

$$
E V_{i, t}=\frac{\ln \left(E V_{i, t}^{\text {raw }} \cdot 10^{9}\right)-\ln \left(E V_{\text {min }} \cdot 10^{9}\right)}{\ln \left(E V_{\text {max }} \cdot 10^{9}\right)-\ln \left(E V_{\text {min }} \cdot 10^{9}\right)}
$$

Data sources, approaches, and assumptions used for calculating each of these components for each mineral commodity were obtained from Nassar and others (2020b). These data were updated to include revised and new information up to year 2018 (the most recent year for which the necessary data were available) from more recent versions of the same data sources used. In a several instances, alternative data sources, approaches, or assumptions were used in this analysis. These instances are detailed in appendix 1 and described briefly below.

\section{Modifications and Additions}

Modifications in the analysis related mainly to the use of certain HTS codes to estimate consumption and net import reliance, the selection of certain NAICS codes, and the data sources for secondary production. For lithium and the REEs, an evaluation of the refining processing step was included in addition to that of the mining stage. Additionally, several commodities on the current CML that were not assessed by Nassar and others (2020b) were assessed here. This included fluorspar, hafnium, and synthetic graphite, which was combined with the previously assessed natural graphite (assessment data are in tables 1.1, 1.2, 1.3). Finally, in addition to the modification of the disruption potential evaluation (eq. 2), in the computation of the WSI, the list of countries included in the "Military Cooperation" component of the WSI are now limited to those with which the United States has an active security 
of supply agreement (U.S. Department of Defense, 2020), namely, Australia, Canada, Finland, Italy, the Netherlands, Norway, Spain, Sweden, and the United Kingdom.

\section{Threshold Criteria}

Determining which mineral commodities should be placed on a CML based on the quantitative assessment requires the development of a cutoff threshold. To do this, threshold criteria were established for each supply risk component individually, as described in table 1.

The resultant supply risk normalized score that corresponds to a commodity meeting each of these threshold criteria - the geometric mean of the three individual components' threshold criteria normalized scores-is 0.40 . Commodities with a mean supply risk of greater than or equal to this threshold, regardless of the individual component scores, would thus be recommended for inclusion on the CML based on the quantitative assessment. To account for recent trends, supply risk scores for more recent years were given more weight. Specifically, a recency-weighted mean was calculated based on the following weights for supply risk scores for 2018, 2017, 2016, and 2015, respectively: 40 percent, 30 percent, 20 percent, and 10 percent. This approach attempts to balance the need to look at recent events and multiyear trends.

Importantly, the quantitative assessment of supply risk provides a continuum of scores from which different mineral commodities can be compared. Developing a CML based on any threshold should not imply that all commodities on the list pose an equal supply risk or that commodities not on the list have no supply risk and can thus be ignored. Indeed, the quantitative assessment suggests that it is more important to focus on commodities that are at or near the top of the list rather than be concerned about whether any single commodity scores just above or below the threshold. Other prioritization mechanisms, such as the cluster analysis used by Nassar and others (2020b), or categorizations based on industry-specific vulnerabilities or the efficacy of supply risk-reducing strategies can also be developed.

\section{Qualitative Evaluation}

Because of the substantial amount of data required, not all mineral commodities were assessed using the quantitative assessment. Specifically, sufficient data were not available to quantitively assess the following commodities that are currently on the CML: cesium, rubidium, and scandium. Additionally, the REEs were categorized on the initial CML as a group but are assessed in this analysis individually. Several REEs, however - namely europium, gadolinium, terbium, holmium, erbium, thulium, ytterbium, and lutetium - were not analyzed individually because of the lack of necessary data. It should be noted that rare earth deposits in nature typically contain the full inventory of REEs in greater or lesser quantities, depending on the deposit. Despite the lack of applicable data, it is useful to split the group into individual elements, to the extent possible, as the applications for individual REEs may be more or less vulnerable to supply disruptions. The Energy Act of 2020 (Public Law 116-260) indicates that qualitative evidence may be used to the extent necessary if the available data are insufficient to provide a quantitative assessment. As such, these commodities were assessed qualitatively based on the information available.

Table 1. Threshold criteria for each supply risk component.

[ASI, ability to supply index; WSI, willingness to supply index]

\begin{tabular}{|c|c|c|c|}
\hline & \multicolumn{3}{|c|}{ Supply risk component } \\
\hline & Disruption potential & Trade exposure & Economic vulnerability \\
\hline $\begin{array}{l}\text { Threshold criteria } \\
\text { description }\end{array}$ & $\begin{array}{l}\text { Global production of the commodity } \\
\text { outside the United States was concen- } \\
\text { trated such that one-half was from a } \\
\text { single country that was less able or less } \\
\text { willing to continue to supply to the } \\
\text { United States than the average country } \\
\text { (specifically defined as the 75th per- } \\
\text { centile ASI and WSI indicators), or an } \\
\text { equivalent production distribution that } \\
\text { resulted in the same normalized score. }\end{array}$ & $\begin{array}{l}\text { One-half of U.S. con- } \\
\text { sumption of the com- } \\
\text { modity was obtained } \\
\text { from foreign sources. }\end{array}$ & $\begin{array}{l}\text { Annual expenditures on the commodity } \\
\text { were equal to the median commodity } \\
\text { expenditure (across all commodities } \\
\text { and years evaluated) in a manufacturing } \\
\text { industry that had a below average ( } 75 \text { th } \\
\text { percentile) operating profits-to-value- } \\
\text { added ratio, or equivalent normalized } \\
\text { score. }\end{array}$ \\
\hline $\begin{array}{l}\text { Normalized score } \\
\text { corresponding to } \\
\text { threshold criteria } \\
(0-1 \text { scale })\end{array}$ & 0.20 & 0.50 & 0.64 \\
\hline
\end{tabular}




\section{Single Point of Failure}

In the quantitative assessment, a mineral commodity for which the United States was a net exporter received a trade exposure score of 0 , resulting in an overall supply risk of 0 . As described by Nassar and others (2020a), net exporter status does not necessarily indicate that the domestic industry is immune to supply disruptions. The United States may, for example, be only a modest net exporter or there may be only a single domestic producer. If that single domestic producer becomes unable to continue operating or decreases production, the United States may become a net importer and exposed to foreign supply disruptions. The concern with risks resulting from a SPOF is expressed in The Strategic and Critical Materials Stock Piling Act, as amended (50 U.S.C. 98), which stipulates the development of a strategic and critical materials stockpile to decrease the "dangerous and costly dependence by the United States upon foreign sources or a single point of failure for supplies of such materials in times of national emergency" (50 U.S.C. 98(b)). In this analysis, a commodity for which there was a domestic SPOF was automatically recommended for inclusion on the CML.

\section{Results}

\section{Quantitative Assessment}

The quantitative assessment methodology described above was applied to 54 nonfuel mineral commodities. This included 16 commodities - aluminum, cerium, cobalt, copper, dysprosium, lanthanum, lead, lithium, neodymium, nickel, praseodymium, tin, titanium, samarium, yttrium, and zinc - that were assessed at multiple supply chain stages (for example, mining and refining). The assessment provided an annual evaluation for each commodity for 2007 through 2018, except where necessary data were not available. The scores for each of the components and the resultant supply risk on a normalized 0-to-1 scale are provided for all applicable years in figure 1. For the 16 commodities for which multiple production stages were evaluated, the highest score among the stages was used for that commodity for that year.

Examining the disruption potential scores in figure $1 \mathrm{~A}$ reveals that some mineral commodities have either consistently low disruption potential (for example, gold and silver) or consistently high disruption potential (for example, magnesium, niobium, REEs, and several PGMs) over the entire period of analysis. This reflects the fact that the global production of such commodities as gold and silver is distributed across many countries, whereas global production of magnesium, niobium, the REEs, and the PGMs is highly concentrated in a single country. In a few cases, however, the disruption potential increased either moderately (for example, tantalum and lithium) or markedly (for example, cobalt and gallium) - a reflection of the increasingly concentrated global production of these mineral commodities. For example, global cobalt mine production has become increasingly concentrated in the Democratic Republic of the Congo, whereas global cobalt refinery production has become increasingly concentrated in China. There were only a few commodities for which the disruption potential generally decreased either during the entire period of analysis (for example, antimony) or decreased after initially increasing (for example, bismuth). This is mainly a reflection of the decreasing share of global production of the leading producer either because that country decreased its production, other countries increased their production, or both (as was the case of antimony). For commodities that were assessed at multiple supply chain stages, the stage that had the higher disruption potential varied by commodity and, in some cases, also varied over time. For cobalt, mine production had the higher disruption potential for all years evaluated, although the disruption potential for cobalt refinery production increased steadily with the increased production concentration in China. For copper, the smelting process had a slightly greater disruption potential than that of the refinery process, whereas the disruption potential for titanium sponge was clearly greater than that of titanium mineral concentrates for all years. For other commodities, including lead, nickel, tin, and zinc, the process with the higher disruption potential varied by year - an indication that the processes had comparable disruption potential.

As displayed in figure $1 B$, several commodities, including arsenic, gallium, indium, iridium, manganese, niobium, ruthenium, strontium, tantalum, and yttrium, had a trade exposure score of 1 for the entire period of analysis, indicating a complete U.S. reliance on imports for domestic consumption. In contrast, helium, gold, and iron ore had a trade exposure score of 0 for the entire period of analysis, indicating that the United States was a net exporter of those commodities. A few commodities, including tellurium and lead, had increasing trade exposure mainly because of their decreasing domestic production and (or) increasing net imports. For commodities that were assessed at multiple supply chain stages, the higher trade exposure was typically for the downstream supply chain processes (for example, smelting or refining). Two exceptions were aluminum and titanium. For aluminum, bauxite had a higher trade exposure than alumina and aluminum. For titanium, titanium mineral concentrates had a higher trade exposure than titanium sponge.

Economic vulnerability scores (displayed in figure $1 C$ ) for many commodities were either consistently high (for example, aluminum and copper) or low (for example, arsenic and cadmium). For a few commodities, such as rhenium, economic vulnerability declined steadily during the period of the analysis. Such instances were typically a reflection of decreasing market prices. Price fluctuations most notably affected the economic vulnerability for the REEs, which increased notably in 2010 and 2011 as a consequence of market fears in response to China's announced export restrictions. Price changes were also the main contributor to the notable changes in ruthenium's economic vulnerability. For commodities that were 
evaluated at multiple supply chain stages, the higher economic vulnerability was consistently associated with the downstream supply chain process (for example, smelting or refining).

As expected, these trends in the individual components were reflected in the overall supply risk (displayed in figure $1 D$ ). Mineral commodities with consistently high supply risk included niobium, several PGMs, and fluorspar (listed under fluorine, "F"), whereas commodities with low supply risk included cadmium, selenium, and mica. Because the United States was a net exporter (had a trade exposure score of 0 ) of gold, iron ore, helium, molybdenum, and zirconium for most or all years of the assessment, these commodities received a supply risk score of 0 for the associated years.

Commodities for which supply risk increased notably during the period of analysis included aluminum, cobalt, gallium, and tantalum. The supply risk also increased steadily for several commodities, including copper, lead, and zinc. A few commodities, including antimony, had steady declines in supply risk. The heavy REEs dysprosium, samarium, and yttrium had decreases in supply risk in the latter years of the assessment owing mainly to decreases in economic vulnerability as a result of decreasing prices from their peak in 2010-11.

Figure 2 displays all supply risk components simultaneously in a scatter plot format for 2018, which was the latest year assessed. In the two-dimensional disruption potentialeconomic vulnerability space of this figure, there was a general trend from the upper left (low disruption potential and high economic vulnerability) to bottom right (high disruption potential and low economic vulnerability). As noted by Nassar and others (2020b), this trend suggests that mineral commodities that are widely used in the economy are those that are produced in many countries, whereas those used in niche applications are those with highly concentrated production. Aside from helium, beryllium, and magnesium, mineral commodities with moderate to high disruption potential were also those with high trade exposure, whereas commodities with low trade exposure tended also to have low disruption potential. Commodities with low scores in all three supply risk components fall into the bottom-left corner and have a small point sizes in figure 2. This included cadmium, mica, and selenium. Commodities with high economic vulnerability but low disruption potential and low trade exposure included copper, iron ore, gold, and lead. Commodities with moderate to high scores on all three dimensions, and thus the highest supply risk, included cobalt, gallium, neodymium, and niobium.

The commodities with the highest supply risk are more readily identified in figure 3 , which displays the supply risk scores across all years in rank order of their recency-weighted mean for the last four assessed years (in which the supply risk scores for 2015, 2016, 2017, and 2018 were weighted 10 percent, 20 percent, 30 percent, and 40 percent, respectively).

Of the 54 mineral commodities evaluated, a total of 36 commodities had a recency-weighted mean supply risk that is greater than or equal to the criteria threshold score of 0.40 . This included gallium, niobium, cobalt, and neodymium, which had the highest recency-weighted mean supply risk scores, and samarium, manganese, lithium, and tellurium, which had recency-weighted mean supply risk scores at or just above the threshold.

Figure 3 also identifies the leading producing country for each mineral commodity based on the cumulative production for the entire period of analysis. For the 16 commodities that were evaluated at multiple production stages, the leading producing country for each stage was identified. Of the 54 mineral commodities evaluated, China was the leading producer of at least one stage of the supply chain for 35 commodities, including 26 of the 36 commodities with the recency-weighted mean supply risk score of at least 0.40 . Other leading producing countries included Australia for bauxite, iron ore, lithium (mined), titanium mineral concentrates, and zirconium; Canada for potash; Chile for copper and rhenium; the Democratic Republic of the Congo for cobalt mining and tantalum; South Africa for chromium, manganese, and PGMs; and the United States for beryllium and helium.

\section{Byproduct Status}

The Energy Act of 2020 (Public Law 116-260) requires the identification of mineral commodities that are recovered as byproducts, as well as the identification of their host commodities. By definition, byproduct commodities are those whose production is dependent on that of another commodity. Commodities that are predominately produced as byproducts, along with their principal host commodities, are identified in figure 3. Importantly, although byproduct status may introduce an additional level of complexity in the supply of these commodities, it is in and of itself not necessarily a contributor to supply risk.

The classification of REEs as byproducts is complicated and requires further clarification. REEs are mined both as byproducts of other mineral commodities (for example, iron ore or heavy-mineral sands) and as the main product. Where REEs are mined as the main product, the individual REEs are either byproducts or coproducts of each other. Depending on the specific economics of each operation, one or more REEs may be the main product, whereas the others may be classified as byproducts. Currently, neodymium-praseodymium (as a single unseparated commodity) is the main revenue generator for most REE mine operations in which REEs are the main product, with the exception of ion-adsorption clays, in which one or more heavy REEs are the major product. In all such cases, however, it is unlikely that any single REE can individually cover the entire cost of sales and make the operation profitable (Nassar and others, 2015). As such, in figure 3, all REEs are labeled as having been produced mostly as byproducts.

Importantly, most commodities are recovered as a byproduct to some degree, but the share of primary production for commodities that are not identified as byproducts in figure 3 is typically small. For example, copper is produced as a byproduct of platinum and nickel mining but is the principal commodity in most operations in which it is recovered. 


\section{A. Disruption potential}

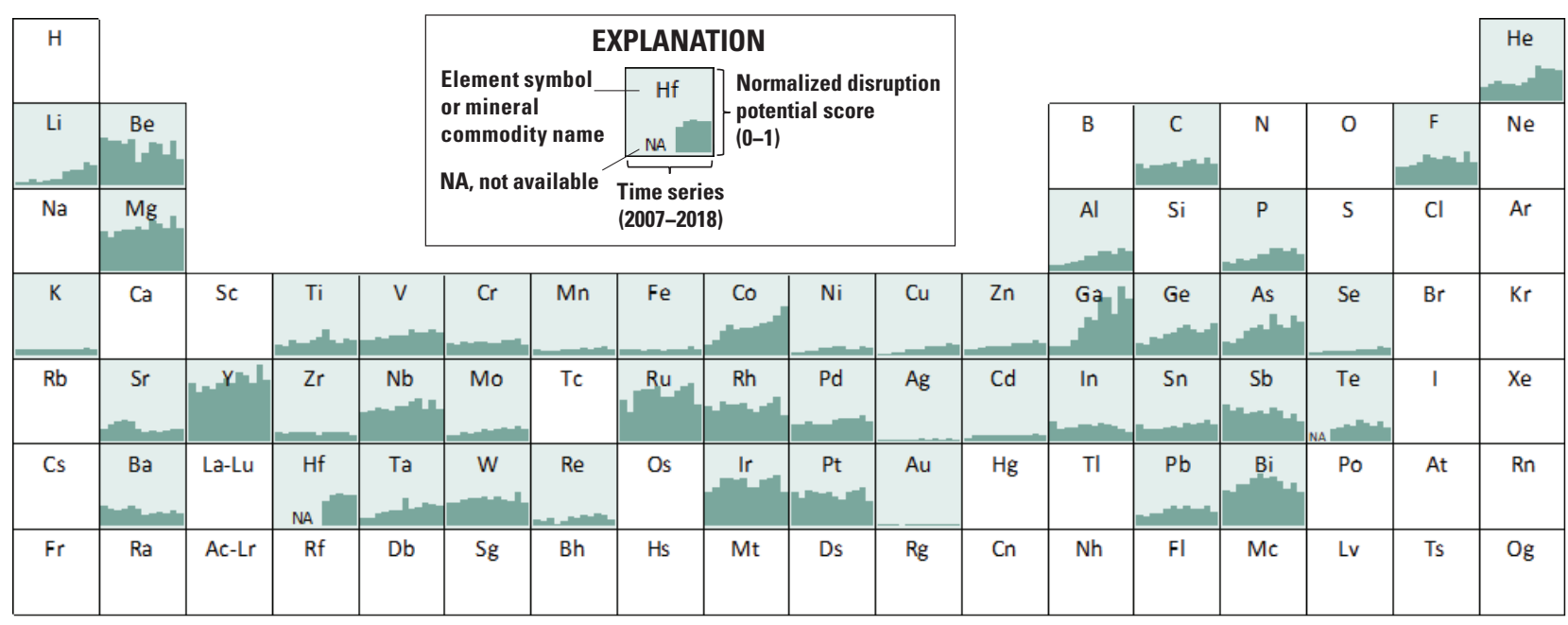

\begin{tabular}{|c|c|c|c|c|c|c|c|c|c|c|c|c|c|c|c|c|}
\hline Lanthanides & $\mathrm{L}$ & $C$ & $P_{r}$ & & Pm & $\mathrm{Sm}$ & Eu & Gd & $\mathrm{Tb}$ & Dy $=1$ & Ho & $\mathrm{Er}$ & $\mathrm{Tm}$ & $\mathrm{Yb}$ & Lu & Feldspar \\
\hline Actinides & $A c$ & Th & $\mathrm{Pa}$ & $\mathrm{U}$ & $\mathrm{Np}$ & $\mathrm{Pu}$ & Am & $\mathrm{Cm}$ & $\mathrm{Bk}$ & Cf & Es & $\mathrm{Fm}$ & Md & No & $\mathrm{Lr}$ & Mica \\
\hline
\end{tabular}

\section{B. Trade exposure}

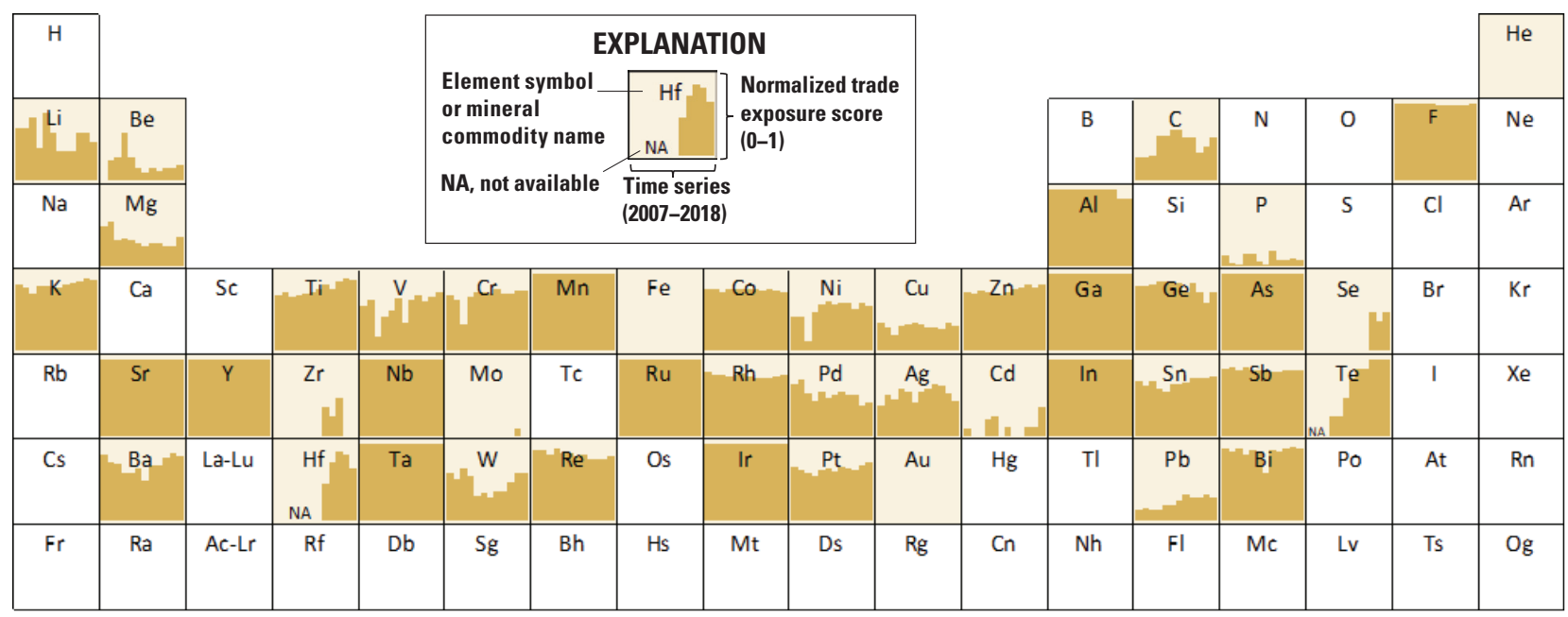

\begin{tabular}{|c|c|c|c|c|c|c|c|c|c|c|c|c|c|c|c|}
\hline Lanthanides & La & $\mathrm{Ce}$ & $\mathrm{Pr}$ & $\mathrm{Nd}$ & $\mathrm{Pm}$ & $\mathrm{Sm}$ & $\mathrm{Eu}$ & $\mathrm{Gd}$ & $\mathrm{Tb}$ & $\mathrm{Dy}$ & $\mathrm{Ho}$ & $\mathrm{Er}$ & $\mathrm{Tm}$ & $\mathrm{Yb}$ & $\mathrm{Lu}$ \\
\hline Actinides & $\mathrm{Ac}$ & $\mathrm{Th}$ & $\mathrm{Pa}$ & $\mathrm{U}$ & $\mathrm{Np}$ & $\mathrm{Pu}$ & $\mathrm{Am}$ & $\mathrm{Cm}$ & $\mathrm{Bk}$ & $\mathrm{Cf}$ & $\mathrm{Es}$ & $\mathrm{Fm}$ & $\mathrm{Md}$ & No & Lr \\
\hline
\end{tabular}

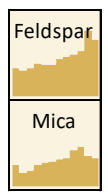

Figure 1. Supply risk indicators for selected mineral commodities from 2007 through 2018. For the 54 mineral commodities assessed (shaded areas) for the period 2007 through 2018, time-series evaluations of the following supply risk indicators are displayed on a periodic table of the elements: $A$, disruption potential; $B$, trade exposure; $C$, economic vulnerability; and $D$, overall supply risk for 2007 through 2018. Normalized indicator scores range from 0 to 1, with higher scores indicating a greater degree of disruption potential, trade exposure, economic vulnerability, or supply risk. For some commodities, indicator scores are rounded to avoid disclosing company proprietary data. The scores for graphite and fluorspar are provided under carbon (" $\mathrm{C}$ ") and fluorine ("F"), respectively, and because no one element is associated with mica or feldspar, these mineral commodities are shown separately. Element symbols are defined in the periodic table provided in the front of the report. 
C. Economic vulnerability

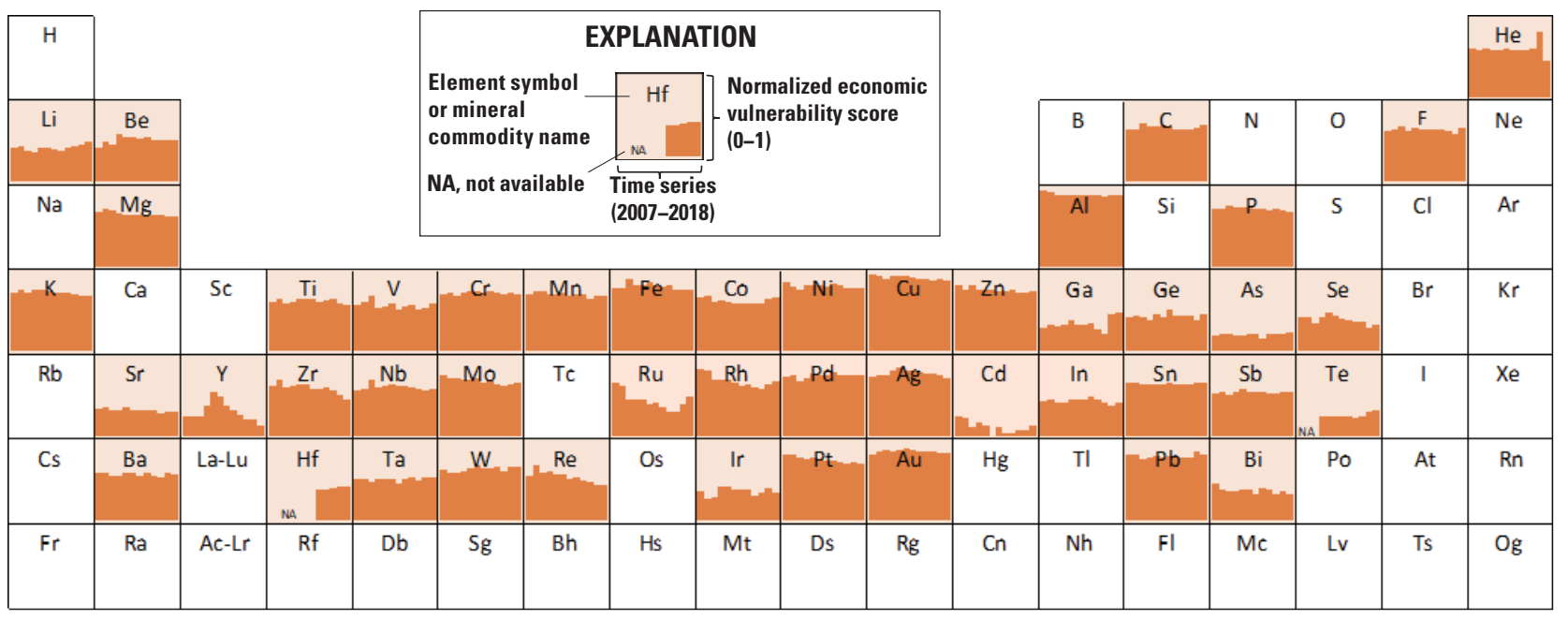

\begin{tabular}{|c|c|c|c|c|c|c|c|c|c|c|c|c|c|c|c|}
\hline Lanthanides & La & $\mathrm{Ce}$ & $\mathrm{Pr}$ & $\mathrm{Nd}$ & $\mathrm{Pm}$ & $\mathrm{Sm}$ & $\mathrm{Eu}$ & $\mathrm{Gd}$ & $\mathrm{Tb}$ & $\mathrm{Dy}$ & Ho & Er & $\mathrm{Tm}$ & $\mathrm{Yb}$ & Lu \\
\hline Actinides & $\mathrm{Ac}$ & $\mathrm{Th}$ & $\mathrm{Pa}$ & $\mathrm{U}$ & $\mathrm{Np}$ & $\mathrm{Pu}$ & $\mathrm{Am}$ & $\mathrm{Cm}$ & $\mathrm{Bk}$ & $\mathrm{Cf}$ & $\mathrm{Es}$ & $\mathrm{Fm}$ & $\mathrm{Md}$ & No & Lr \\
\hline
\end{tabular}

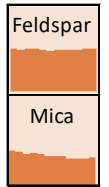

\section{Supply risk}

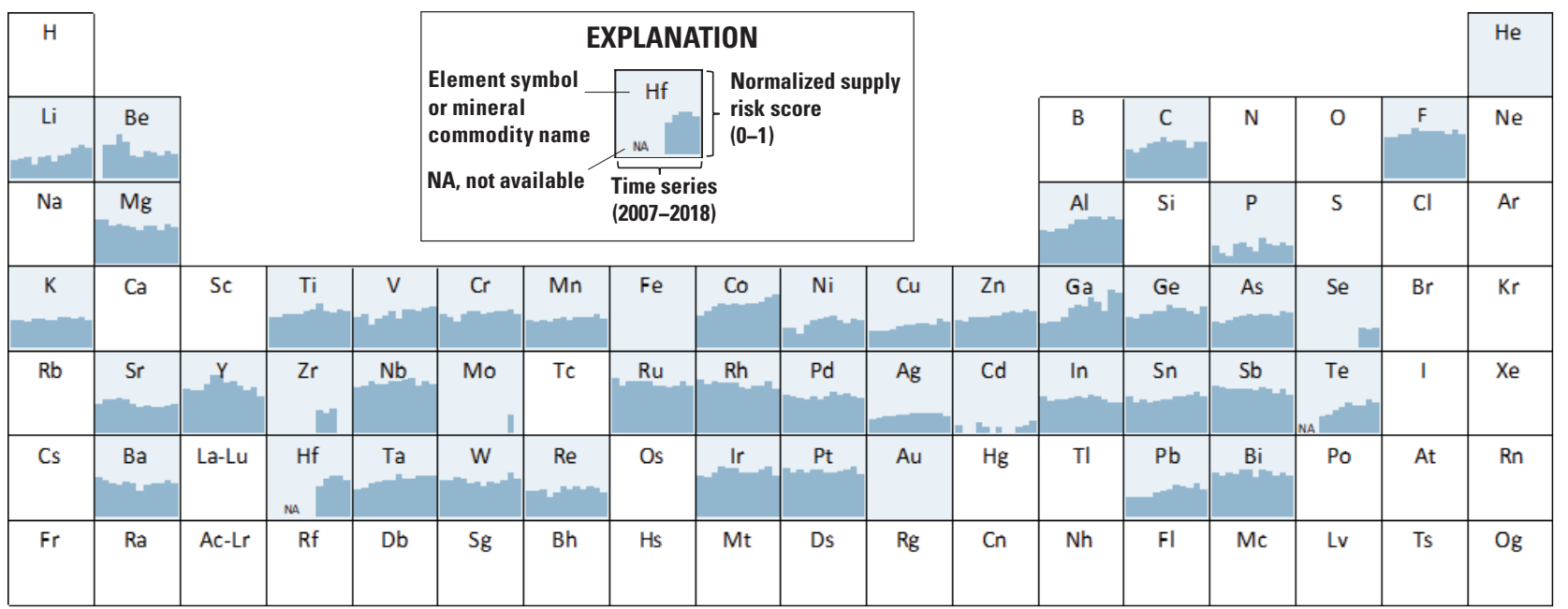

\begin{tabular}{|c|c|c|c|c|c|c|c|c|c|c|c|c|c|c|c|}
\hline Lanthanides & La & $\mathrm{Ce}$ & $\mathrm{Pr}$ & $\mathrm{Nd}$ & $\mathrm{Pm}$ & $\mathrm{Sm}$ & $\mathrm{Eu}$ & $\mathrm{Gd}$ & $\mathrm{Tb}$ & $\mathrm{Dy}$ & $\mathrm{Ho}$ & $\mathrm{Er}$ & $\mathrm{Tm}$ & $\mathrm{Yb}$ & $\mathrm{Lu}$ \\
\hline Actinides & $\mathrm{Ac}$ & $\mathrm{Th}$ & $\mathrm{Pa}$ & $\mathrm{U}$ & $\mathrm{Np}$ & $\mathrm{Pu}$ & $\mathrm{Am}$ & $\mathrm{Cm}$ & $\mathrm{Bk}$ & $\mathrm{Cf}$ & $\mathrm{Es}$ & $\mathrm{Fm}$ & $\mathrm{Md}$ & $\mathrm{No}$ & $\mathrm{Lr}$ \\
\hline
\end{tabular}

Figure 1.-Continued 


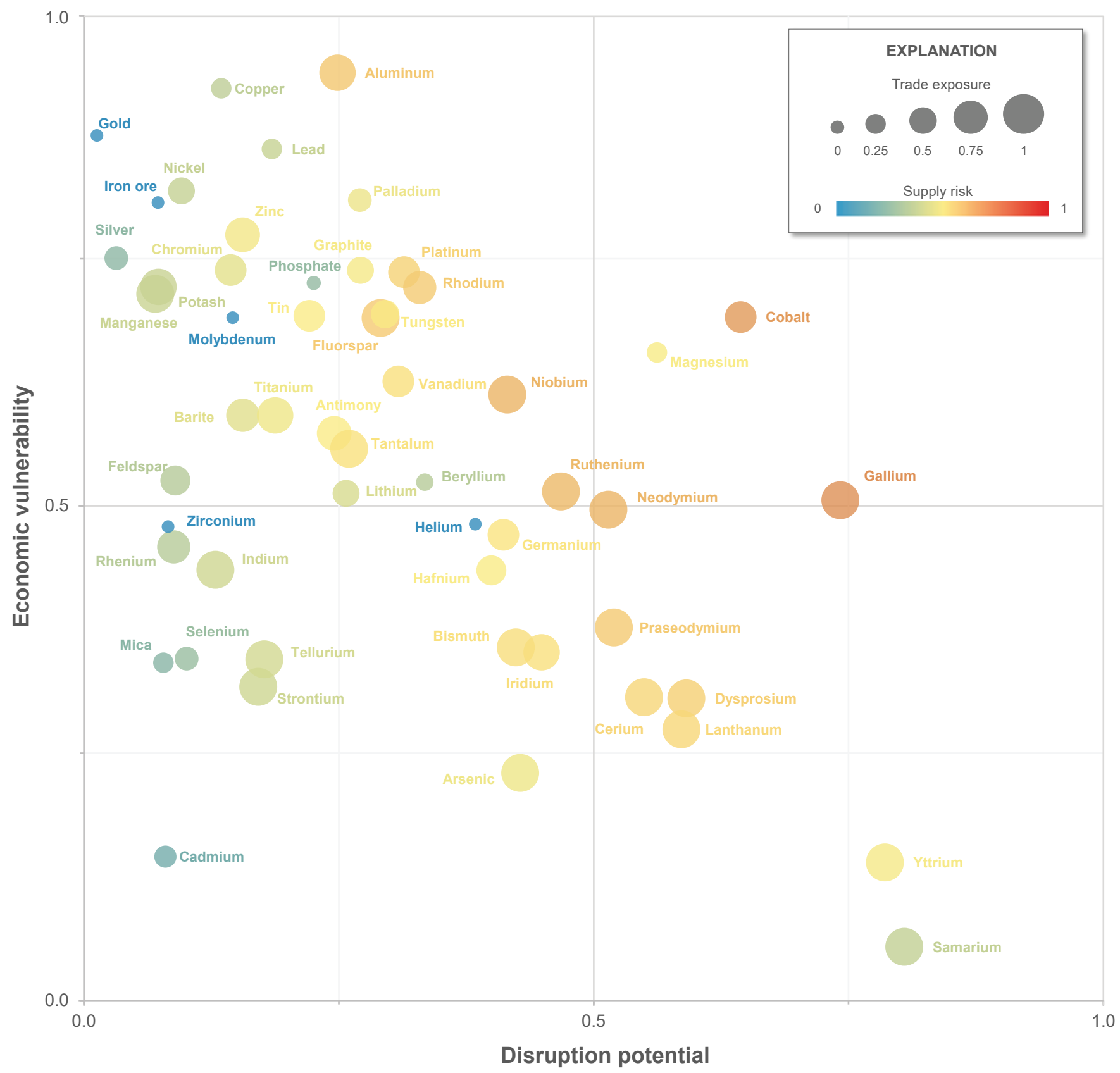

Figure 2. Assessment of mineral commodity supply risk. The graph shows the disruption potential (horizontal axis), economic vulnerability (vertical axis), trade exposure (point size), and overall supply risk (point shade) for various mineral commodities in 2018. For some commodities, indicator scores are rounded to avoid disclosing company proprietary data.

Another important consideration is that byproduct status can change. For example, tantalum was previously recovered mainly as a byproduct of tin slag. Although it is still recovered as a byproduct of tin slag, the share of global tantalum production coming from tin slag is currently small (Nassar, 2017). Similarly, tantalum is currently recovered as a byproduct of lithium production in Australia. The share of tantalum recovered as a byproduct is also currently small but is poised to increase in the future. For most commodities, however, byproduct status does not change notably over short periods of time. A more comprehensive treatment of byproduct status can be found in references dealing explicitly with this topic (Nassar and others, 2015; Schulz and others, 2017).

\section{Single Point of Failure}

Of the commodities assessed that do not meet the quantitative threshold criteria, three have a domestic SPOF: beryllium, nickel, and zirconium. For beryllium, a single company 


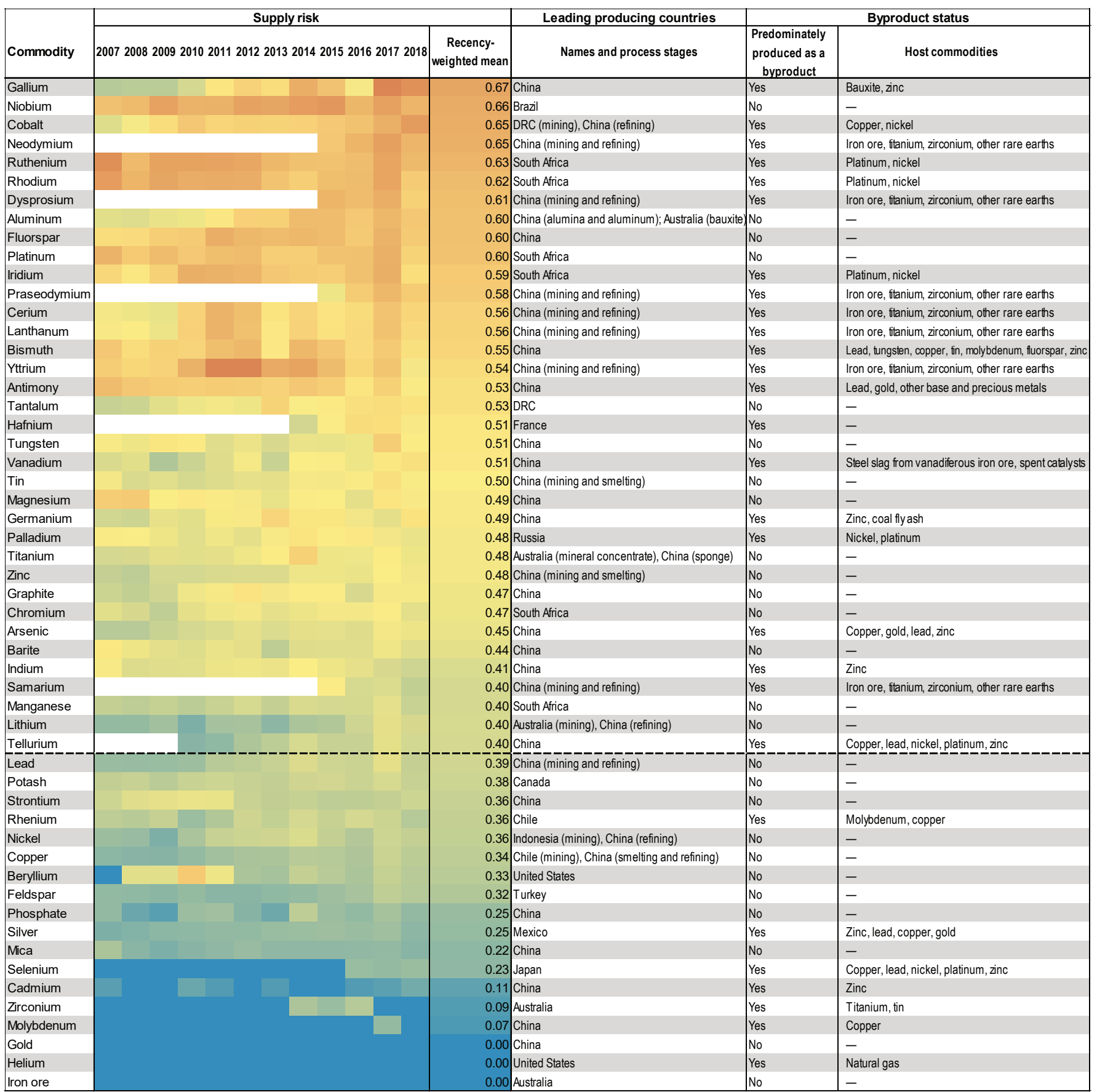

Supply risk

Low risk High risk

Figure 3. Heat map displaying the supply risk for all mineral commodities examined for 2007 through 2018. Warmer (that is, orange to red) shades indicate a greater degree of supply risk. Commodities are listed in descending order of their recency-weighted mean supply risk score, which was calculated using quantitative criteria for 2015 through 2018, as described in the "Methodology" section of this report. Commodities with a recency-weighted mean supply risk score greater than or equal to 0.40 (as indicated by the dashed horizonal line) are recommended for inclusion on the Critical Minerals List based on the quantitative criteria. Years for which insufficient data were available are not colored. The leading producing country listing is based on the countries' cumulative production for the entire period of analysis for the different stages of production or commodity forms, where applicable. No host commodities are listed for commodities that are not predominately produced as byproducts. The list of host commodities is not exhaustive. Information on byproduct status was obtained mostly from Nassar and others (2015). DRC, Democratic Republic of the Congo. 
is both the sole domestic ore producer and processor (Lederer and others, 2016; U.S. Geological Survey, 2020). The output of this single producer from its mine in Spor Mountain, Utah, and its processing facility in Elmore, Ohio, made the United States the world's leading producer of beryllium and beryllium products (Lederer and others, 2016; U.S. Geological Survey, 2020). Because of its importance to defense applications, beryllium has been designated as a strategic material by the U.S. Department of Defense (National Research Council, 2008; Lederer and others, 2016).

Domestically, nickel is mined from an underground mine in Michigan (U.S. Geological Survey, 2020). Concentrates from that mine were exported for processing outside the United States (U.S. Geological Survey, 2020). Starting in 2019, nickel was also recovered from mine tailings as part of the U.S. Environmental Protection Agency's Superfund Redevelopment Initiative (U.S. Geological Survey, 2020). However, there was only one operation (located in Montana) that produced nickel in crystalline sulfate as a byproduct of smelting and refining of PGMs (U.S. Geological Survey, 2020).

In the United States, two firms recovered zircon-the principal source of zirconium - as a byproduct of heavymineral sands and a third company recovered zircon from heavy-mineral-sand tailings (U.S. Geological Survey, 2020). Two companies also produced zirconium metal domestically (U.S. Geological Survey, 2020). There was no domestic producer of zirconium oxychloride (ZOC), however, and only one domestic producer fused zircon (zirconium oxide powder), both of which are necessary precursors for the production of zirconium metal (U.S. Trade Representative, 2019). Because of this and the importance of zirconium metal in a variety of strategic applications, both ZOC and fused zircon were recommended for exclusion from Section 301 duties under the Trade Act of 1974 (U.S. Trade Representative, 2019).

\section{Qualitative Evaluation}

As previously noted, there were insufficient data to assess several commodities that are on the initial CML: cesium, rubidium, scandium, and several REEs. The United States has been completely net import reliant for all these commodities for many years (U.S. Geological Survey, 2020). No specific global production data were available for these commodities; however, general information suggests that production for each of these commodities is highly concentrated in countries that may rate unfavorably on the ASI or the WSI. Scandium was noted to have been produced mainly as a byproduct in China, Kazakhstan, the Philippines, Russia, and Ukraine (U.S. Geological Survey, 2020). Cesium and rubidium had been produced in Australia, Canada, China, Namibia, and Zimbabwe; however, it is thought that all cesium and rubidium mine production outside of China has ceased in recent years (U.S. Geological Survey, 2021). In Namibia, cesium and rubidium mine production is thought to have ceased in the early 2000s; in Canada, mining operations at the Tanco Mine were limited after a mine collapse in 2015 and the mine was subsequently sold to a Chinese company; in Zimbabwe, pollucite ore at the Bikita Mine was depleted in 2018; and in Australia, mining of all economically recoverable pollucite ore from the Sinclair Mine was completed in 2019 (U.S. Geological Survey, 2021). The REEs that were not analyzed because of the lack of data (namely europium, gadolinium, terbium, holmium, erbium, thulium, ytterbium, and lutetium) were all heavy REEs that were produced only or predominantly in China. Based on this qualitative evaluation, none of these commodities are recommended for removal from the CML.

\section{Discussion}

\section{Comparison to the Initial Critical Minerals List}

The list of mineral commodities that are recommended for inclusion on the CML in this analysis (and the basis for that recommendation) is provided and compared to those on the initial CML in table 2. Aside from zinc, all the commodities above the quantitative threshold are on the initial CML. Of the three commodities that do not meet the quantitative threshold but do meet the SPOF criteria (beryllium, nickel, and zirconium), only nickel is not on the initial CML. As a result, both zinc and nickel are recommended for addition to the CML. Although the recommendation for including nickel and zinc on the CML is based on methodological changes, there are changes in their supply and demand that are noteworthy. For example, demand for nickel for use in lithium-ion batteries is currently only a small percentage of its total demand, but that demand is expected to grow markedly as demand for electric vehicles increases in the coming years. For zinc, global mine and smelter production concentration has increased notably during the past few decades. This change has been driven mainly by increased production in China (Nassar and others, 2020a). Concurrently, one of two domestic primary zinc smelters halted operations in about 2005 and operational issues and temporary suspension of operations at a secondary zinc smelter (that is, a producer from recycled feedstocks) resulted in a comparatively lower level of secondary production between 2014 and 2019. The smelter reopened in 2020 and is currently ramping up toward its full production rate.

The commodities that are currently on the CML but that neither meet the quantitative threshold nor have a SPOF are helium, potash, rhenium, and strontium. Notably, potash, strontium, and rhenium have recency-weighted mean supply risk scores of $0.38,0.36$, and 0.36 , respectively-just below the quantitative threshold of 0.40 . This highlights the fact that the metrics developed with this methodology are best viewed as a continuum of supply risk rather than an as indication that supply risk does not exist for commodities below the quantitative cutoff. These three commodities all had very high trade 
Table 2. Overview of mineral commodity assessment, ranking, and categorization for inclusion on the draft Critical Minerals List in 2021.

[CML, Critical Minerals List; SPOF, single point of failure]

\begin{tabular}{|c|c|c|c|c|}
\hline $\begin{array}{c}\text { Quantitative } \\
\text { assessment rank1 }\end{array}$ & Mineral commodity & $\begin{array}{c}\text { Recommended for } \\
\text { inclusion on draft CML? }\end{array}$ & $\begin{array}{l}\text { Basis for recommended } \\
\text { inclusion on draft CML }\end{array}$ & On initial CML? \\
\hline 1 & Gallium & Yes & Quantitative assessment & Yes \\
\hline 2 & Niobium & Yes & Quantitative assessment & Yes \\
\hline 3 & Cobalt & Yes & Quantitative assessment & Yes \\
\hline 4 & Neodymium & Yes & Quantitative assessment & Yes \\
\hline 5 & Ruthenium & Yes & Quantitative assessment & Yes \\
\hline 6 & Rhodium & Yes & Quantitative assessment & Yes \\
\hline 7 & Dysprosium & Yes & Quantitative assessment & Yes \\
\hline 8 & Aluminum & Yes & Quantitative assessment & Yes \\
\hline 9 & Fluorspar & Yes & Quantitative assessment & Yes \\
\hline 10 & Platinum & Yes & Quantitative assessment & Yes \\
\hline 11 & Iridium & Yes & Quantitative assessment & Yes \\
\hline 12 & Praseodymium & Yes & Quantitative assessment & Yes \\
\hline 13 & Cerium & Yes & Quantitative assessment & Yes \\
\hline 14 & Lanthanum & Yes & Quantitative assessment & Yes \\
\hline 15 & Bismuth & Yes & Quantitative assessment & Yes \\
\hline 16 & Yttrium & Yes & Quantitative assessment & Yes \\
\hline 17 & Antimony & Yes & Quantitative assessment & Yes \\
\hline 18 & Tantalum & Yes & Quantitative assessment & Yes \\
\hline 19 & Hafnium & Yes & Quantitative assessment & Yes \\
\hline 20 & Tungsten & Yes & Quantitative assessment & Yes \\
\hline 21 & Vanadium & Yes & Quantitative assessment & Yes \\
\hline 22 & Tin & Yes & Quantitative assessment & Yes \\
\hline 23 & Magnesium & Yes & Quantitative assessment & Yes \\
\hline 24 & Germanium & Yes & Quantitative assessment & Yes \\
\hline 25 & Palladium & Yes & Quantitative assessment & Yes \\
\hline 26 & Titanium & Yes & Quantitative assessment & Yes \\
\hline 27 & Zinc & Yes & Quantitative assessment & No \\
\hline 28 & Graphite & Yes & Quantitative assessment & Yes \\
\hline 29 & Chromium & Yes & Quantitative assessment & Yes \\
\hline 30 & Arsenic & Yes & Quantitative assessment & Yes \\
\hline 31 & Barite & Yes & Quantitative assessment & Yes \\
\hline 32 & Indium & Yes & Quantitative assessment & Yes \\
\hline 33 & Samarium & Yes & Quantitative assessment & Yes \\
\hline 34 & Manganese & Yes & Quantitative assessment & Yes \\
\hline 35 & Lithium & Yes & Quantitative assessment & Yes \\
\hline 36 & Tellurium & Yes & Quantitative assessment & Yes \\
\hline 37 & Lead & No & Not applicable & No \\
\hline 38 & Potash & To be determined ${ }^{2}$ & Not applicable & Yes \\
\hline 39 & Strontium & To be determined ${ }^{2}$ & Not applicable & Yes \\
\hline 40 & Rhenium & To be determined ${ }^{2}$ & Not applicable & Yes \\
\hline 41 & Nickel & Yes & SPOF & No \\
\hline
\end{tabular}


Table 2. Overview of mineral commodity assessment, ranking, and categorization for inclusion on the draft Critical Minerals List in 2021.-Continued

[CML, Critical Minerals List; SPOF, single point of failure]

\begin{tabular}{|c|c|c|c|c|}
\hline $\begin{array}{c}\text { Quantitative } \\
\text { assessment rank1 }\end{array}$ & Mineral commodity & $\begin{array}{c}\text { Recommended for } \\
\text { inclusion on draft CML? }\end{array}$ & $\begin{array}{l}\text { Basis for recommended } \\
\text { inclusion on draft CML }\end{array}$ & On initial CML? \\
\hline 42 & Copper & No & Not applicable & No \\
\hline 43 & Beryllium & Yes & SPOF & Yes \\
\hline 44 & Feldspar & No & Not applicable & No \\
\hline 45 & Phosphate & No & Not applicable & No \\
\hline 46 & Silver & No & Not applicable & No \\
\hline 47 & Mica & No & Not applicable & No \\
\hline 48 & Selenium & No & Not applicable & No \\
\hline 49 & Cadmium & No & Not applicable & No \\
\hline 50 & Zirconium & Yes & SPOF & Yes \\
\hline 51 & Molybdenum & No & Not applicable & No \\
\hline 52 & Gold & No & Not applicable & No \\
\hline 53 & Helium & To be determined ${ }^{2}$ & Not applicable & Yes \\
\hline 54 & Iron ore & No & Not applicable & No \\
\hline (3) & Cesium & Yes & Qualitative evaluation & Yes \\
\hline (3) & Erbium & Yes & Qualitative evaluation & Yes \\
\hline (3) & Europium & Yes & Qualitative evaluation & Yes \\
\hline (3) & Gadolinium & Yes & Qualitative evaluation & Yes \\
\hline (3) & Holmium & Yes & Qualitative evaluation & Yes \\
\hline (3) & Lutetium & Yes & Qualitative evaluation & Yes \\
\hline (3) & Rubidium & Yes & Qualitative evaluation & Yes \\
\hline (3) & Scandium & Yes & Qualitative evaluation & Yes \\
\hline (3) & Terbium & Yes & Qualitative evaluation & Yes \\
\hline (3) & Thulium & Yes & Qualitative evaluation & Yes \\
\hline (3) & Uranium & Not evaluated & Not applicable & Yes \\
\hline (3) & Ytterbium & Yes & Qualitative evaluation & Yes \\
\hline
\end{tabular}

1Ranking order from highest to lowest based on a recency-weighted mean of the commodities' overall supply risk scores.

${ }^{2}$ Commodities that were on the initial CML but that do not meet either the quantitative assessment or the SPOF criteria will be subject to further discussion through the interagency process for a decision on whether they should remain or be removed from the CML.

${ }^{3}$ Commodities that were not evaluated using the quantitative assessment are not given a rank and are ordered alphabetically.

exposure but low disruption potential. This is a reflection that the United States was highly net import reliant on all three commodities but that the production of these commodities was either not highly concentrated or was concentrated in countries that were rated favorable on the ASI or the WSI.

The production of potash is not highly concentrated, and the leading global producer and supplier to the United States was Canada. Strontium's production was somewhat more concentrated than that of potash, and several countries - including Spain, China, Mexico, and Iran - were major producers. The United States obtained most of its strontium minerals from Mexico (U.S. Geological Survey, 2020). Production of rhenium was highly concentrated, but the leading producer was Chile - a country with very favorable WSI and ASI scores.
The United States is a major producer of both primary and secondary rhenium but, as a leading consumer of rhenium, domestic demand far exceeds domestic supply, resulting in a high degree of net import reliance.

Rhenium and potash had high economic vulnerability, which is a reflection of their use in superalloys in turbine blades and fertilizer, respectively. In contrast, the economic vulnerability for strontium was relatively low owing to its limited use and low price. Moreover, whereas there is no effective substitute for potash as a fertilizer, barium is preferred over celestite (strontium sulfate) in drilling muds and can substitute for strontium in ferrite magnets. For rhenium, major manufacturing firms have taken steps to reduce their use of this geologically scarce metal by developing superalloys that use 
low or no rhenium, by reducing the amount of scrap generated during the casting process through additive manufacturing, by recovering the grindings and scrap generated during the fabrication and manufacturing processes, and by recycling engine parts at the end of their useful life (Konitzer and others, 2012; Roskill Information Services Ltd., 2019). Many of these efforts were initiated at a time when rhenium prices (for both rhenium metal powder and ammonium perrhenate) reached a peak of more than $\$ 10,000$ per kilogram in 2008 in response to anticipated shortages in the face of rapidly increasing demand (U.S. Geological Survey, 2013; Roskill Information Services Ltd., 2019). The onset of the global economic recession and the associated slowdown in the aerospace market in 2009, along with previously mentioned initiatives, decreased the demand for and increased the supply of rhenium. As a result, rhenium prices have since been steadily declining and averaged approximately $\$ 1,000$ per kilogram in 2020 (U.S. Geological Survey, 2021). Importantly, sales of rhenium are typically made under long-term, fixed-price contracts, especially for rhenium metal (Roskill Information Services Ltd., 2019). These contracts provide a level of market stability for both rhenium suppliers and consumers. As previously noted, these steadily decreasing prices have resulted in declining economic vulnerability scores for rhenium, which in turn resulted in a recency-weighted mean supply risk score that is just below the quantitative threshold.

The fourth commodity that was on the initial CML but does not meet the quantitative threshold nor the SPOF criteria is helium. The United States is the world's leading producer and a net exporter of helium. Helium's trade exposure was thus 0 and, in turn, its supply risk was 0 . Crude helium was produced in more than a dozen plants across several States, and several other plants produced grade-A helium (U.S. Geological Survey, 2021). Helium, therefore, does not qualify for inclusion on the CML based on the SPOF criteria. Helium production outside the United States was concentrated in Qatar and Algeria. Both of these countries, as well as Canada, Russia, and Tanzania, are poised to increase their production as additional capacity becomes available in the near future (Bettenhausen, 2020; Kramer, 2020).

Helium supply shortages have occurred sporadically during the past two decades (Bettenhausen, 2020). The most recent disruptions were associated with political tensions between Qatar and its neighboring countries (Anderson, 2018; Reisch, 2019; Kramer, 2020). The disruptions have resulted in higher prices and, in some cases, actual shortages (Bettenhausen, 2020). In response, some consumers have attempted to reduce or eliminate the use of helium from their processes, whereas others have installed recovery and recycling systems (Bettenhausen, 2020; Kramer, 2020). Disruptions in global helium supply generally reflect a lack of supply chain flexibility both on the supply side and the demand side (Anderson, 2018). Factors that contribute to helium's supply and demand inelasticity may include the commodity's recovery as a byproduct of natural gas, notable barriers to market entry, difficulties of its recovery and recycling, regulatory issues, and the lack of a viable substitute, especially in cryogenic applications where temperatures below 17 Kelvin are required (Anderson, 2018; Kramer, 2020; U.S. Geological Survey, 2021).

The disposal of the remaining Federal helium inventory and assets by the Bureau of Land Management by September 2021 (U.S. Geological Survey, 2021) has the potential to remove the buffer that has provided a level of market stability and to increase the level of uncertainty in the market (Bahl, 2019; Bettenhausen, 2020). The shift from conventional natural gas towards shale gas, which lacks recoverable quantities of helium, also has the potential to reduce the supply of helium, especially for the United States (Bahl, 2019; Bettenhausen, 2020).

Finally, although uranium has important nonfuel uses, its formal definition as a fuel mineral excludes it from consideration here. The same applies to noncombustion uses of fossil fuels, including petroleum for its use as a petrochemical feedstock for making plastics, lubricants, asphalt, waxes, and polishes; natural gas for its use in nitrogenous fertilizers; and coal tars used in sealcoats, synthetic dyes, paints, and skin treatment products (Francis, 2018). Moreover, issues regarding the availability and reliability of nuclear fuel supplies are addressed in a separation section (Public Law 116-260, Title II, "Nuclear") of the Energy Act of 2020.

\section{Additional Issues for Consideration}

Several additional considerations in the analysis of supply risk may warrant further investigation in future iterations of this assessment. Many of these factors are discussed by Nassar and others (2020a) and are described briefly here.

The current assessment of disruption potential focuses on intentional and unintentional manmade disruptions. There are other potential sources of disruptions, however, including those caused by natural hazards, that may be important to consider (Schnebele and others, 2019). Foreign ownership of mineral assets is another issue that may affect the disruption potential. Certain mineral assets and associated processing facilities in one country are controlled by another. In situations of heightened trade tensions or conflict, foreign-owned assets controlled by rival nations may be less secure than those controlled by their host nations. The ability for suppliers to react and adjust to disruptions is yet another factor to consider. The ability to offset disrupted supplies by using excess available capacity (or the ability to increase capacity quickly and costeffectively), tapping into Government and industry inventories, and other means may significantly decrease the effect of supply disruptions.

Similarly, several issues may obscure the true import reliance of the United States. One such issue is that of embedded trade reliance. Embedded trade reliance refers to U.S. reliance on mineral commodities through imports of finished and semifinished goods that contain or require mineral commodities for their manufacture. For example, the United States imports 
flat-panel displays and other electronics that contain indium. This is in addition to the indium that the United States imports in raw material forms. Information on the quantity of imported indium and other mineral commodities embedded in finished and semifinished goods is not readily available, however, and so the full extent of the U.S. import reliance on them is not readily apparent. Moreover, the United States likely imports finished goods from a different set of countries than those from which it imports raw materials. Including the import reliance of embedded materials would provide an assessment for not only the supply risk to U.S. manufacturers but also the final consumers of these goods.

A complementary effort could examine how supply disruptions at the front of a supply chain may ripple through and affect downstream industries and the final consumers. Additionally, the evaluation of the viability for alternative materials, technologies, or systems to offset some of the demand for disrupted materials can be used to help refine the economic vulnerability component. A more detailed investigation into the stability of domestic producers, such as their financial viability, their ability to access basic inputs, and their ability to compete with foreign supplies, could also improve the SPOF evaluation.

The assessment conducted in this analysis focuses on supply risk. There are, however, also concerns regarding demand shocks - situations in which demand increases significantly faster than supply, resulting in higher prices that affect consuming industries. The rapid market penetration of electric vehicles may, for example, increase demand for lithium-ion battery materials, such as cobalt, flake graphite, lithium, nickel, and manganese, as well as rare earths for permanent magnets, faster than producers are able to increase supplies. Some of these concerns may (eventually) be alleviated by market mechanisms, such as substitution, that can decrease demand or, if high prices are sustained, result in new or expanded operations that increase primary or secondary (that is, recycling) supply. For example, vehicle manufacturers are already exploring the feasibility of using lithium-ion battery chemistries that reduce or eliminate the need for cobalt. Nevertheless, understanding how these factors may develop under different scenarios could help minimize the effect that these demand shocks may have on consuming industries, especially those industries that are not able to (or cannot continue to) pay the higher prices.

The development of future scenarios could help determine how each supply risk component may change in the future under varying supply and demand based on the underlying socioeconomic, technological, and policy uncertainties. Additional investigation could help determine whether such factors can and should be incorporated in future assessments. It may be possible to evaluate these factors quantitatively for several commodities, but current data limitations may make it difficult to perform such an evaluation across the entire suite of commodities.

\section{Conclusion}

The United States is highly reliant on imports for a large and growing number of mineral commodities whose production is concentrated in a few countries. This high degree of import reliance exposes the United States to potential foreign supply disruptions to which domestic manufacturing industries may be vulnerable. Using a risk-modeling framework, these factors were evaluated quantitatively and, in certain cases qualitatively, to determine which mineral commodity supply chains posed the greatest supply risk to the United States. Of the 54 commodities evaluated using the quantitative assessment, 36 had a recency-weighted mean supply risk score that exceeded a criteria-based threshold. An additional three commodities (beryllium, nickel, and zirconium) had a SPOF along their supply chain. Several commodities on the initial CML (cesium, rubidium, scandium, europium, gadolinium, terbium, holmium, erbium, thulium, ytterbium, and lutetium) that could not be assessed quantitatively were evaluated qualitatively and found to have notable risks associated with their supply. Overall, of the commodities evaluated, only two commodities (nickel and zinc) that are not on the initial CML are recommended for inclusion on the updated draft CML and four commodities (helium, potash, rhenium, and strontium) on the initial CML did not meet either the quantitative threshold nor the SPOF criteria.

Each commodity is important to the specific applications in which it is used. The removal of any commodity from the CML should therefore not be viewed as a lack of its importance. In the current analysis, the attempt has been made to focus on categorizing and prioritizing commodities based on their supply risk to the United States, which includes but is not limited to a commodity's importance to the U.S. economy.

Given the complexity of global supply chains, it is also important to recognize that no single assessment can perfectly capture all the intricacies that can affect a commodity's supply risk. Nevertheless, the methodology presented here provides a useful, transparent, and defensible basis for identifying and prioritizing commodities based on objective measures. Efforts to enhance and expand the methodology presented here may improve future assessments to better anticipate and mitigate risk to the U.S. economy and national security.

\section{References Cited}

\author{
Anderson, S.T., 2018, Economics, helium, and the \\ U.S. Federal Helium Reserve-Summary and outlook: \\ Natural Resources Research, v. 27, no. 4, p. 455-477, \\ accessed April 9, 2021, at https://doi.org/10.1007/ \\ s11053-017-9359-y.
}


Bahl, S., 2019, Helium-Macro view update: New York, New York, Edison Investment Research, Inc., 19 p., accessed April 9, 2021, at https://www.edisongroup.com/ wp-content/uploads/2019/02/HeliumMacroUpdate2019.pdf.

Bettenhausen, C., 2020, How helium shortages have changed science: Chemical \& Engineering News, October 21, accessed April 9, 2021, at https:/cen.acs.org/business/ specialty-chemicals/Podcast-helium-shortages-changedscience/98/web/2020/10. [Transcript of podcast.]

Crichton, D., 1999, The risk triangle, in Ingleton, J., ed., Natural disaster management: London, United Kingdom, Tudor Rose, p. 102-103.

Fortier, S.M., DeYoung, J.H., Jr., Sangine, E.S., and Schnebele, E.K., 2015, Comparison of U.S. net import reliance for nonfuel mineral commodities-A 60-year retrospective (1954-1984-2014): U.S. Geological Survey Fact Sheet 2015-3082, 4 p., accessed April 9, 2021, at https://doi.org/10.3133/fs20153082.

Fortier, S.M., Nassar, N.T., Lederer, G.W., Brainard, J., Gambogi, J., and McCullough, E.A., 2018, Draft critical mineral list-Summary of methodology and background information-U.S. Geological Survey technical input document in response to Secretarial Order No. 3359: U.S. Geological Survey Open-File Report 2018-1021, 15 p., accessed April 9, 2021, at https://doi.org/10.3133/ ofr20181021.

Francis, M., 2018, About 7\% of fossil fuels are consumed for non-combustion use in the United States: U.S. Energy Information Administration website, accessed April 9, 2021, at https://www.eia.gov/todayinenergy/detail.php?id=35672\#.

Jowitt, S.M., 2020, COVID-19 and the global mining industry: SEG Discovery, v. 122, p. 33-41, accessed April 9, 2021, at https://pubs.geoscienceworld.org/segweb/segdiscovery/ article-standard/doi/10.5382/SEGnews.2020-122.fea-02/ 588289/COVID-19-and-the-Global-Mining-Industry.

Konitzer, D., Duclos, S., and Rockstroh, T., 2012, Materials for sustainable turbine engine development: MRS Bulletin, v. 37, no. 4, p. 383-387, accessed April 9, 2021, at https://doi.org/10.1557/mrs.2012.35.

Kramer, D., 2020, Helium shortage has ended, at least for now: Physics Today, v. 2020, no. 2, article 0605a, accessed April 9, 2021, at https://doi.org/10.1063/PT.6.2.20200605a.

Lederer, G.W., Foley, N.K., Jaskula, B.W., and Ayuso, R.A., 2016, Beryllium-A critical mineral commodityResources, production, and supply chain: U.S. Geological Survey Fact Sheet 2016-3081, 4 p., accessed April 9, 2021, at http://pubs.er.usgs.gov/publication/fs20163081.
Nassar, N.T., 2017, Shifts and trends in the global anthropogenic stocks and flows of tantalum: Resources, Conservation and Recycling, v. 125, p. 233-250, accessed April 9, 2021, at https://doi.org/ 10.1016/j.resconrec.2017.06.002.

Nassar, N.T., Alonso, E., and Brainard, J., 2020a, Investigation of U.S. foreign reliance on critical minerals - U.S. Geological Survey technical input document in response to Executive Order No. 13953 signed September 30, 2020: U.S. Geological Survey Open-File Report 2020-1127, 37 p., accessed April 9, 2021, at https://doi.org/10.3133/ofr20201127.

Nassar, N.T., Brainard, J., Gulley, A., Manley, R., Matos, G., Lederer, G., Bird, L.R., Pineault, D., Alonso, E., Gambogi, J., and Fortier, S.M., 2020b, Evaluating the mineral commodity supply risk of the U.S. manufacturing sector: Science Advances, v. 6, no. 8, article eaay8647, accessed April 9, 2021, at https://doi.org/10.1126/ sciadv.aay 8647.

Nassar, N.T., and Fortier, S.M., 2020, U.S. mineral supply chain security in the age of pandemics and trade wars [original article revised by A. Sela]: The Science Breaker, accessed April 9, 2021, at https://doi.org/10.25250/ thescbr.brk421.

Nassar, N.T., Graedel, T.E., and Harper, E.M., 2015, By-product metals are technologically essential but have problematic supply: Science Advances, v. 1, no. 3, article e1400180, accessed April 9, 2021, at https://doi.org/ 10.1126/sciadv. 1400180 .

National Research Council, 2008, Managing materials for a twenty-first century military: Washington, D.C., The National Academies Press, 206 p.

National Science and Technology Council, 2016, Assessment of critical minerals - Screening methodology and initial application: Washington, D.C., National Science and Technology Council, 47 p.

Reisch, M.S., 2019, Help for helium users is on the way: Chemical and Engineering News, v. 97, no. 46, accessed April 9, 2021, at https://cen.acs.org/business/ instrumentation/Help-helium-users-way/97/i46.

Roskill Information Services Ltd, 2019, Rhenium-Outlook to 2029 (11th ed.): London, United Kingdom, Roskill Information Services Ltd., 238 p.

Schnebele, E., Jaiswal, K., Luco, N., and Nassar, N.T., 2019, Natural hazards and mineral commodity supplyQuantifying risk of earthquake disruption to South American copper supply: Resources Policy, v. 63, article 101430, accessed April 9, 2021, at https://doi.org/ 10.1016/j.resourpol.2019.101430. 
Schulz, K.J., DeYoung, J.H., Jr., Seal, R.R., II, and Bradley, D.C., eds., 2017, Critical mineral resources of the United States-Economic and environmental geology and prospects for future supply: U.S. Geological Survey Professional Paper 1802, 797 p., accessed April 9, 2021, at https://doi.org/10.3133/pp1802.

Stedman, A., Yunis, J., and Aliakbari, E., 2020, Annual survey of mining companies 2019: Vancouver, British Columbia, Canada, Fraser Institute, 76 p.

U.S. Department of Commerce, 2019, A Federal strategy to ensure secure and reliable supplies of critical minerals: U.S. Department of Commerce, 50 p., accessed April 9, 2021, at https:/www.commerce.gov/sites/default/ files/2020-01/Critical_Minerals_Strategy_Final.pdf.

U.S. Department of Defense, 2020, Security of supply: U.S. Department of Defense Office of Industrial Policy website, accessed April 9, 2021, at https://www.businessde fense.gov/security-of-supply/.
U.S. Department of Energy, 2020, Restoring America's competitive nuclear energy advantage - A strategy to assure U.S. national security: U.S. Department of Energy, accessed April 9, 2021, at https:/www.energy.gov/sites/prod/files/ 2020/04/f74/Restoring America\%27s Competitive Nuclear Advantage-Blue version \%5B1\%5D.pdf

U.S. Department of the Interior, 2018, Final list of critical minerals 2018: Federal Register, v. 83, no. 97, p. 23295-23296, accessed April 9, 2021, at https://www. federalregister.gov/documents/2018/05/18/2018-10667/ final-list-of-critical-minerals-2018.

U.S. Geological Survey, 2013, Mineral commodity summaries 2013: Reston, Va., U.S. Geological Survey, 198 p.

U.S. Geological Survey, 2020, Mineral commodity summaries 2020: Reston, Va., U.S. Geological Survey, 200 p.

U.S. Geological Survey, 2021, Mineral commodity summaries 2021: Reston, Va., U.S. Geological Survey, 200 p.

U.S. Trade Representative, 2019, Section 301 tariffs public hearing: U.S. Trade Representative 301 Committee, 485 p., accessed April 9, 2021, at https:/ustr.gov/sites/default/ files/enforcement/301Investigations/Section_301_Hearing_ Transcript_on_Proposed_Tariffs_Day_3.pdf. 


\section{Appendix 1. Modifications and Additions to the Assessment}

\section{Modifications}

This assessment was conducted following the methodology used by Nassar and others (2020) using more recent versions of the same data sources along with some modifications. Specifically, the evaluation of disruption (eq. 2) weights the square of the production shares by the ability to supply index (ASI) or willingness to supply index (WSI) (whichever is greater) rather than by both the ASI and the WSI. This is done to reflect that supply disruptions may occur if a producing country is either unable or unwilling (rather than being both unable and unwilling) to continue to supply the United States.

Additionally, in the computation of the WSI, the list of countries included in the "Military Cooperation" component of the WSI are now limited to those with which the United States has an active security of supply agreement (U.S. Department of Defense, 2020), namely: Australia, Canada, Finland, Italy, the Netherlands, Norway, Spain, Sweden, and the United Kingdom.

Commodity-specific deviations from the data sources, approaches, and (or) assumptions used by Nassar and others (2020) are detailed below. The description of the modifications made for rare earths appears at the end of this section.

\section{Aluminum}

- Data on secondary aluminum production by country were obtained from the World Bureau of Metal Statistics (2020).

\section{Antimony}

- Data for secondary production and stock changes for the United States were obtained from U.S. Geological Survey (2012-2020; 2020) Minerals Yearbooks (including individual advance release chapters) and Mineral Commodity Summaries.

- End-use fractions, which were originally based on reported primary antimony consumption, have been modified to account for consumption of secondary antimony, all of which is assumed to be consumed in the manufacturing of lead-acid batteries.

- Harmonized Tariff Schedule (HTS) code 2620.91.0000 was removed from both the imports and exports, as its antimony content is not reliably known. Overall quantities are small.

\section{Arsenic}

- Trade data for gallium arsenide wafers, undoped (HTS code 2853.00.0010) were not available for 2017 and 2018. The mirror trade (that is, what other countries reported as their exports to the United States) were used instead for those years.

\section{Beryllium}

- Trade data under HTS code 8112.19.0000 have been added.

\section{Cobalt (Refinery)}

- China's secondary (recycling) refining production quantities were obtained from Darton Commodities Ltd. (2008-2020).

\section{Chromium}

- Export data for the following HTS codes were not available from the U.S. Census Bureau (2018) starting in 2015 for HTS codes 2819.10.0000 and 2814.30.0000 and starting in 2016 for HTS code 2819.90.0000. Data from the mirror trade (that is, what other countries reported as their imports from the United States) were used instead for those years.

\section{Gallium}

- Import data for gallium arsenide wafers, undoped (HTS code 2853.00.0010) were not available for 2017 and 2018. The mirror trade (that is, what other countries reported as their exports to the United States) were used instead for those years.

- Because U.S. exports of gallium are not reported, the mirror trade (that is, what other countries reported as their imports from the United States) were used instead.

\section{Helium}

- The helium price used was changed to be based on grade-A helium instead of crude helium. 


\section{Lithium}

- Lithium refinery production was added using data from Roskill Information Services Ltd. (2019a).

\section{Magnesium Metal}

- Secondary production quantities for countries other than the United States were added based on estimates from Roskill Information Services Ltd. (2020b). These quantities were based on reported capacities.

\section{Molybdenum}

- Superalloys consumption was moved from the steels category to the nonferrous metal category, with the addition of the following North American Industry Classification System (NAICS) codes: 332117 , 333611, and 336412.

\section{Niobium}

- Superalloys were split from the steels category to form a separate superalloys category with the following NAICS codes: 331492, 332117, 333611, and 336412.

\section{Tin (Smelter)}

- For the alloys category, the following NAICS code was removed: 325910.

\section{Titanium (Sponge)}

- The following import HTS codes with an assumed titanium content of 1 were added: 8108.90 .6031 , 8108.90.6045, 8108.90.6060, and 8108.90.6075.

- The following export HTS code with an assumed titanium content of 1 was added: 8108.90.6031.

\section{Tungsten}

- For the steel and alloys category, the following NAICS codes were added: 331491, 331492, 332117, 333611, and 336412 .

\section{Vanadium}

- For the non-aluminum and superalloy category, the following NAICS codes were added: 332117,333611 , and 336412 .

\section{Zinc (Mine)}

- The following export HTS codes were removed: 2620.11.0000 and 2620.19.0000.

\section{Rare Earth Production and Consumption}

\section{World Mine Production}

Total rare earth oxide (TREO) mine production quantities were obtained from the latest U.S. Geological Survey Minerals Yearbooks (including individual advance release chapters; U.S. Geological Survey, 2020) and Mineral Commodity Summaries (U.S. Geological Survey, 2012-2020) and distributed among individual rare earth elements (REEs) based on the distributions used by Nassar and others (2020) for all producing countries except China.

China's TREO mine production was obtained from Roskill Information Services Ltd. (2019b). This total was delineated between "official" and "unofficial" production by Roskill Information Services Ltd. (2019b). The official production portion was further delineated between the various producing Provinces (Fujian, Guangdong, Guangxi, Hunan, Inner Mongolia, Shandong, and Sichuan) as reported for year 2019 by Roskill Information Services Ltd. (2019b). The distribution between these Provinces for the official production was assumed not to vary over the timespan covered in this analysis.

For the unofficial production portion, estimates of production by year and by region (Northern region: Inner Mongolia and Shandong Provinces; Central region: Sichuan Province; and Southern region: Fujian, Guangdong, Guangxi, Jiangxi, and Yunnan Provinces) were obtained from Roskill Information Services Ltd. (2018b). Unofficial production for the Northern region was further split between Inner Mongolia and Shandong Provinces based on the proportions of their official production for the year 2019. For the unofficial production of the Southern region, production was further split between the individual Provinces based on their reported production quota.

The estimated official and unofficial TREO production by individual Province was then distributed among individual REEs based on the distributions used by Nassar and others (2020) for each Province and their associated stochiometric ratios. For Provinces with multiple distributions (Guangdong and Jiangxi), the production was split equally between distributions. 


\section{World Refinery Production}

In addition to rare earth mine production, rare earth refinery production was estimated by country and elements, but only for 2014 through 2018. In this analysis, "refining" refers to the production of separated rare earth compounds (RECs). During the timespan of this analysis, production of separated RECs was thought to have taken place in the following countries: China, Estonia, France, India, Japan, Kazakhstan, Malaysia, Russia, Thailand, the United States, and Vietnam. Brazil and Burma (also known as Myanmar) produced mixed RECs but not separated RECs. Their production was thus excluded in this analysis. Light rare earth elements (light REEs) refers to lanthanum, cerium, praseodymium, and neodymium and SEG+ refers to samarium, europium, gadolinium and a mix of heavy rare earth elements (heavy REEs).

For China, production of separated RECs was obtained from Roskill Information Services Ltd. (2019b). The distribution among individual REEs was assumed to be the same as that of mine production.

For Estonia, production of separated RECs was derived from mixed RECs imported from Russia and the United States under the Harmonized System (HS) code 2846. Total production was approximated based on these import quantities and assumed to be 50 percent of the gross weight of the imports reported from the United States for 2014 and 2015 and from Russia for 2016 through 2018. The distribution among individual REEs was based on the source country's distribution for the applicable year and limited to the light REEs. For the United States, the distribution was based on that of Mountain Pass Mine (Molycorp Inc., 2015). For Russia, the distribution was based on the loparite ore at the Lovozero complex (Hedrick and others, 1997).

For France, because of uncertainties regarding the operation of rare earth separation operations, TREO production was assumed to be a constant 300 metric tons per year based on exports under HS code 2846. For the light REEs, the distribution among individual REEs was assumed to be similar to that of Mt. Weld's Central Lanthanide deposit's light REEs (Lynas Corporation Ltd., 2012).

For India, mixed REC production from IREL (India) Ltd.'s Orissa Sands Complex monazite processing plant was excluded from this analysis. IREL did, however, provide mixed RECs to Toyota Tsusho Corp., which separated them. Only Toyota Tsusho's separated RECs (commissioned in 2016) was thus included (Toyota Tsusho Corp., 2015). TREO production was assumed to be 200 metric tons in 2016 and 1,000 metric tons in 2017 and in 2018. The distribution among individual REEs was limited to the light REEs and assumed to be similar to that of IREL's monazite ore (Roskill Information Services Ltd., 2019b).

For Japan, two companies (Santoku Corp. and Shin-Etsu Chemical Co., Ltd.) were each assumed to have produced an average of 500 metric tons per year of TREO from recycling of magnet scrap. The distribution among individual REEs was assumed to be similar to that of neodymium permanent magnets (specifically, 70 percent neodymium, 23.3 percent praseodymium, and 6.7 percent dysprosium). In addition, a third company, Nippon Yttrium Co. Ltd., was assumed to have produced 100 metric tons per year of yttrium oxide.

For Kazakhstan, production was approximated on the basis of reported exports under HS code 2846, which was assumed to be 50 percent content for 2014 and 2015. The distribution among individual REEs was assumed to be similar to that of Russia's loparite ore.

For Malaysia, production of separated RECs was based on reported production by Lynas Corporation Ltd. (2013-2020). The distribution among individual REEs was based on Mt. Weld's Central Lanthanide deposit and limited to light REEs (Lynas Corporation Ltd., 2012).

For Russia, separated REC production was based on reported production by JSC Solikamsk Magnesium Works (2019). The distribution among individual REEs was assumed to be the same as that of Russia's mine production (Hedrick and others, 1997). Additionally, a small amount of separated RECs was reported to have been produced by the ACRON Group (2018).

For Thailand, separated REC production was based on exports under HS code 2846. Lynas Corporation's monazite mine distribution among individual REEs was used as a proxy (Lynas Corporation Ltd., 2012). Any SEG+ production was assumed to be exported to China.

For the United States, production of separated RECs was based on reported production by Molycorp Inc. for 2014 and 2015 (Molycorp Inc., 2015). The distribution among individual REEs was based on the distribution reported for the ore (Molycorp Inc., 2015) for light REEs, of which the remainder consisted of an SEG+ mixed concentrate.

For Vietnam, separated REC production was approximated on the basis of exports under HS code 280530. Two companies, Shin-Etsu Magnetic Materials Vietnam Co., Ltd. and Vietnam Rare Earth Ltd. (which was owned by Shenghe Resources Holding Co. Ltd.), were assumed to produce 1,500 metric tons and 500 metric tons, respectively, for each year except 2014, in which Shin-Etsu Magnetic Materials Vietnam was assumed to have produced only 1,000 metric tons. The elemental distribution was assumed to be similar to that of neodymium permanent magnets (specifically, 70 percent neodymium, 23.3 percent praseodymium, and 6.7 percent dysprosium). In addition, Vietnam Rare Earth JSC in Ha Nam Province was assumed to have produced 1,500 metric tons per year, the distribution of which was assumed to be similar to that used for China overall but limited to the products noted on the company's website (Vietnam Rare Earth JSC, 2016).

\section{U.S. Rare Earth Consumption and Net Import Reliance}

The same method employed by Nassar and others (2020) to estimate U.S. rare earth consumption is used in this analysis using the updated estimates by Roskill Information Services Ltd. (2019b). For 2016 through 2018, U.S. net import reliance 
was assumed to be 100 percent for all REEs because no separated RECs were produced in the United States during those years. Furthermore, no separation of samarium, dysprosium, or yttrium was thought to have taken place during any of the years covered in this analysis. For all other years, the U.S. net import reliance of lanthanum, cerium, praseodymium, and neodymium was calculated as the difference between U.S. production and consumption, as a percentage of that consumption.

\section{Additions}

The following tables describe the data sources, approaches, and assumptions used in the assessment of three mineral commodities not previously evaluated by Nassar and others (2020)_fluorspar, graphite, and hafnium. 
Table 1.1. Description of data for world primary and secondary production and prices for each newly evaluated commodity—Fluorspar and graphite (2007-2018) and hafnium (2014-2018).

$\left[\mathrm{CaF}_{2}\right.$, calcium fluoride; metspar, metallurgical-grade fluorspar; acidspar, acid-grade fluorspar; HF, hydrofluoric acid; $\mathrm{AlF}_{3}$, aluminum fluoride $]$

\begin{tabular}{|c|c|c|c|c|c|c|c|c|}
\hline \multirow[b]{2}{*}{ Commodity } & \multicolumn{3}{|c|}{ World primary production } & \multicolumn{3}{|c|}{ World secondary production } & \multicolumn{2}{|l|}{ Prices } \\
\hline & Description & Assumed content & Reference & Description & $\begin{array}{l}\text { Assumed } \\
\text { content }\end{array}$ & Reference & Description & Reference \\
\hline Fluorspar & $\begin{array}{l}\text { Production of } \\
\text { fluorspar (all } \\
\text { grades) }\end{array}$ & $\begin{array}{l}\text { Quantities were assumed to } \\
\text { be, on average, } 96 \text { per- } \\
\text { cent } \mathrm{CaF}_{2} \text {, which were } \\
\text { then adjusted to fluorine } \\
\text { content using the stan- } \\
\text { dard stoichiometric ratio } \\
\text { ( } 48.7 \text { percent) to yield } \\
\text { an overall content of } \\
46.7 \text { percent }\end{array}$ & $\begin{array}{l}\text { (Roskill } \\
\text { Information } \\
\text { Services } \\
\text { Ltd., 2020a; } \\
\text { U.S. Geological } \\
\text { Survey, } \\
\text { 2012-2020, } \\
\text { 2020) }\end{array}$ & Not available & $\begin{array}{l}\text { Not appli- } \\
\text { cable }\end{array}$ & Not applicable & $\begin{array}{l}\text { Annual average U.S. unit im- } \\
\text { port price by form (metspar, } \\
\text { acidspar, } \mathrm{HF}, \mathrm{AlF}_{3} \text { ). These } \\
\text { price estimates by form } \\
\text { were used to estimate } \\
\text { expenditure for the different } \\
\text { end-use categories }\end{array}$ & $\begin{array}{c}\text { (U.S. Census } \\
\text { Bureau, } \\
\text { 2018) }\end{array}$ \\
\hline Graphite & $\begin{array}{l}\text { Natural and } \\
\text { synthetic } \\
\text { graphite } \\
\text { production } 1\end{array}$ & 100 percent & $\begin{array}{l}\text { (Roskill } \\
\text { Information } \\
\text { Services } \\
\text { Ltd., 2018a; } \\
\text { U.S. Geological } \\
\text { Survey, } \\
\text { 2012-2020, } \\
\text { 2020) }\end{array}$ & Not available & $\begin{array}{l}\text { Not appli- } \\
\text { cable }\end{array}$ & Not applicable & $\begin{array}{l}\text { Flake graphite, amorphous } \\
\text { graphite, synthetic graph- } \\
\text { ite, and graphite electrode } \\
\text { prices were based on annual } \\
\text { average U.S. unit import } \\
\text { prices. Prices were then } \\
\text { assigned to each end use on } \\
\text { the basis of the composi- } \\
\text { tion of forms consumed in } \\
\text { North America for that end } \\
\text { use as reported by Roskill } \\
\text { Information Services Ltd. } \\
\text { (2017, 2018a) }\end{array}$ & $\begin{array}{c}\text { (U.S. Census } \\
\text { Bureau, } \\
2018 \text { ) }\end{array}$ \\
\hline Hafnium & $\begin{array}{l}\text { Hafnium } \\
\text { recovered as } \\
\text { a byproduct } \\
\text { of zirconium } \\
\text { metal produc- } \\
\text { tion }\end{array}$ & 100 percent & $\begin{array}{l}\text { (Petra Capital } \\
\text { Pty Ltd., } \\
\text { 2015; Alkane } \\
\text { Resources Ltd., } \\
\text { 2017a, b) }\end{array}$ & $\begin{array}{c}\text { Recycled } \\
\text { revert }\end{array}$ & 100 percent & $\begin{array}{l}\text { (Petra Capital } \\
\text { Pty Ltd., } \\
\text { 2015; } \\
\text { Alkane } \\
\text { Resources } \\
\text { Ltd., } \\
2017 \text { a. b) }\end{array}$ & $\begin{array}{l}\text { Annual average U.S. unit } \\
\text { import price }\end{array}$ & $\begin{array}{l}\text { (U.S. Census } \\
\text { Bureau, } \\
2018 \text { ) }\end{array}$ \\
\hline
\end{tabular}

1The production of synthetic graphite in "Europe" and "Other countries" as provided in the reference were disaggregated equally among the countries identified as being included in these categories because more granular information was not available. 
Table 1.2. Description of data for U.S. apparent consumption calculation by component for each newly evaluated commodity—Fluorspar and graphite (2007-2018) and ha?(2014-2018).

[HTS, Harmonized Tariff Schedule]

\begin{tabular}{|c|c|c|c|c|c|c|c|c|c|c|}
\hline \multirow[b]{2}{*}{ Commodity } & \multicolumn{2}{|c|}{ U.S. primary production } & \multicolumn{2}{|c|}{ U.S. secondary production } & \multicolumn{2}{|c|}{ U.S. imports } & \multicolumn{2}{|c|}{ U.S. exports } & \multicolumn{2}{|c|}{ Stock changes } \\
\hline & Description & References & Description & References & HTS code & $\begin{array}{c}\text { Assumed } \\
\text { content }\end{array}$ & HTS code & $\begin{array}{c}\text { Assumed } \\
\text { content }\end{array}$ & Description & References \\
\hline \multirow[t]{6}{*}{ Fluorspar } & \multirow{6}{*}{$\begin{array}{l}\text { Production of } \\
\text { fluorspar } \\
\text { (all grades) }\end{array}$} & \multirow{6}{*}{$\begin{array}{l}\text { (Roskill } \\
\quad \text { Information } \\
\text { Services Ltd., } \\
\text { 2020a) }\end{array}$} & \multirow{6}{*}{$\begin{array}{l}\text { Not avail- } \\
\text { able }\end{array}$} & \multirow{6}{*}{$\begin{array}{l}\text { Not appli- } \\
\text { cable }\end{array}$} & 2529.21 .0000 & 0.455038131 & 2529.21 .0000 & 0.455038131 & \multirow{6}{*}{$\begin{array}{l}\text { Consumer } \\
\text { and } \\
\text { distributor } \\
\text { stocks of } \\
\text { fluorspar }\end{array}$} & \multirow{6}{*}{$\begin{array}{l}\text { (U.S. Geological } \\
\text { Survey, } \\
\text { 2012-2020, } \\
\text { 2020) }\end{array}$} \\
\hline & & & & & 2529.22 .0000 & 0.47937172 & 2529.22 .0000 & 0.47937172 & & \\
\hline & & & & & 2530.90 .1000 & 0.54296338 & 2530.90 .1000 & 0.54296338 & & \\
\hline & & & & & 2811.11.0000 & 0.94961091 & 2811.11 .0000 & 0.94961091 & & \\
\hline & & & & & 2826.12 .0000 & 0.678702271 & 2826.12 .0000 & 0.678702271 & & \\
\hline & & & & & 2826.30 .0000 & 0.54296338 & 2826.30 .0000 & 0.54296338 & & \\
\hline \multirow[t]{14}{*}{ Graphite } & \multirow{14}{*}{$\begin{array}{l}\text { Synthetic } \\
\text { graphite } \\
\text { production } \\
\text { (no } \\
\text { U.S. natu- } \\
\text { ral } \\
\text { graphite } \\
\text { produc- } \\
\text { tion) }\end{array}$} & \multirow{14}{*}{$\begin{array}{l}\text { (U.S. Geological } \\
\text { Survey, } \\
\text { 2012-2020, } \\
2020)\end{array}$} & \multirow{14}{*}{$\begin{array}{l}\text { Not avail- } \\
\text { able }\end{array}$} & \multirow{14}{*}{$\begin{array}{l}\text { Not appli- } \\
\text { cable }\end{array}$} & 2504.10 .1000 & 1 & 2504.10 .0000 & 1 & \multirow[t]{14}{*}{ Not available } & \multirow[t]{14}{*}{ Not applicable } \\
\hline & & & & & 2504.10 .5000 & 1 & 2504.90 .0000 & 1 & & \\
\hline & & & & & 2504.90 .0000 & 1 & 3801.10 .0000 & 1 & & \\
\hline & & & & & 3801.10 .1000 & 1 & 3801.20 .0000 & 1 & & \\
\hline & & & & & 3801.10 .5000 & 1 & 3801.30 .0000 & 1 & & \\
\hline & & & & & 3801.20 .0000 & 1 & 3801.90 .0000 & 1 & & \\
\hline & & & & & 3801.30 .0000 & 1 & 8545.11 .0000 & 1 & & \\
\hline & & & & & 3801.90 .0000 & 1 & 8545.20 .0000 & 1 & & \\
\hline & & & & & 8545.11 .0000 & 1 & 8545.90 .0000 & 1 & & \\
\hline & & & & & 8545.11 .0010 & 1 & & & & \\
\hline & & & & & 8545.11 .0020 & 1 & & & & \\
\hline & & & & & 8545.11 .0050 & 1 & & & & \\
\hline & & & & & 8545.20 .0000 & 1 & & & & \\
\hline & & & & & 8545.90 .4000 & 1 & & & & \\
\hline
\end{tabular}


Table 1.2. Description of data for U.S. apparent consumption calculation by component for each newly evaluated commodity-Fluorspar and graphite (2007-2018) and haf?(2014-2018).-Continued

[HTS, Harmonized Tariff Schedule]

\begin{tabular}{|c|c|c|c|c|c|c|c|c|c|c|}
\hline \multirow[b]{2}{*}{ Commodity } & \multicolumn{2}{|c|}{ U.S. primary production } & \multicolumn{2}{|c|}{ U.S. secondary production } & \multicolumn{2}{|c|}{ U.S. imports } & \multicolumn{2}{|c|}{ U.S. exports } & \multicolumn{2}{|c|}{ Stock changes } \\
\hline & Description & References & Description & References & HTS code & $\begin{array}{c}\text { Assumed } \\
\text { content }\end{array}$ & HTS code & $\begin{array}{c}\text { Assumed } \\
\text { content }\end{array}$ & Description & References \\
\hline Hafnium & $\begin{array}{l}\text { Hafnium } \\
\text { recovered } \\
\text { as a by- } \\
\text { product of } \\
\text { zirconium } \\
\text { metal pro- } \\
\text { duction }\end{array}$ & $\begin{array}{l}\text { (Petra Capital } \\
\text { Pty Ltd., } \\
\text { 2015; Alkane } \\
\text { Resources } \\
\text { Ltd., 2017a, b) }\end{array}$ & $\begin{array}{l}\text { Not avail- } \\
\text { able }\end{array}$ & $\begin{array}{l}\text { Not appli- } \\
\text { cable }\end{array}$ & $\begin{array}{l}8112.92 .2000 \\
\text { The import code } \\
\text { for wrought } \\
\text { hafnium } \\
(8112.99 .9000) \\
\text { is combined } \\
\text { with other } \\
\text { commodities } \\
\text { and cannot } \\
\text { readily be } \\
\text { disaggregated. } \\
\text { It was thus } \\
\text { excluded from } \\
\text { this analysis. }\end{array}$ & 1 & $\begin{array}{l}\text { Hafnium's } \\
\text { exports } \\
\text { codes are } \\
\text { combined } \\
\text { with other } \\
\text { commodi- } \\
\text { ties and } \\
\text { cannot } \\
\text { readily be } \\
\text { disaggregat- } \\
\text { ed. Exports } \\
\text { were thus } \\
\text { excluded } \\
\text { from this } \\
\text { analysis, } \\
\text { which } \\
\text { increases } \\
\text { the trade ex- } \\
\text { posure and } \\
\text { economic } \\
\text { vulnerability } \\
\text { component } \\
\text { scores. }\end{array}$ & Not applicable & Not available & Not applicable \\
\hline
\end{tabular}


Table 1.3. Description of applications, associated NAICS codes, and U.S. demand fraction for each newly evaluated commodity—Fluorspar and graphite (2007-2018) and hafnium (2014-2018).

[NAICS, North American Industry Classification System]

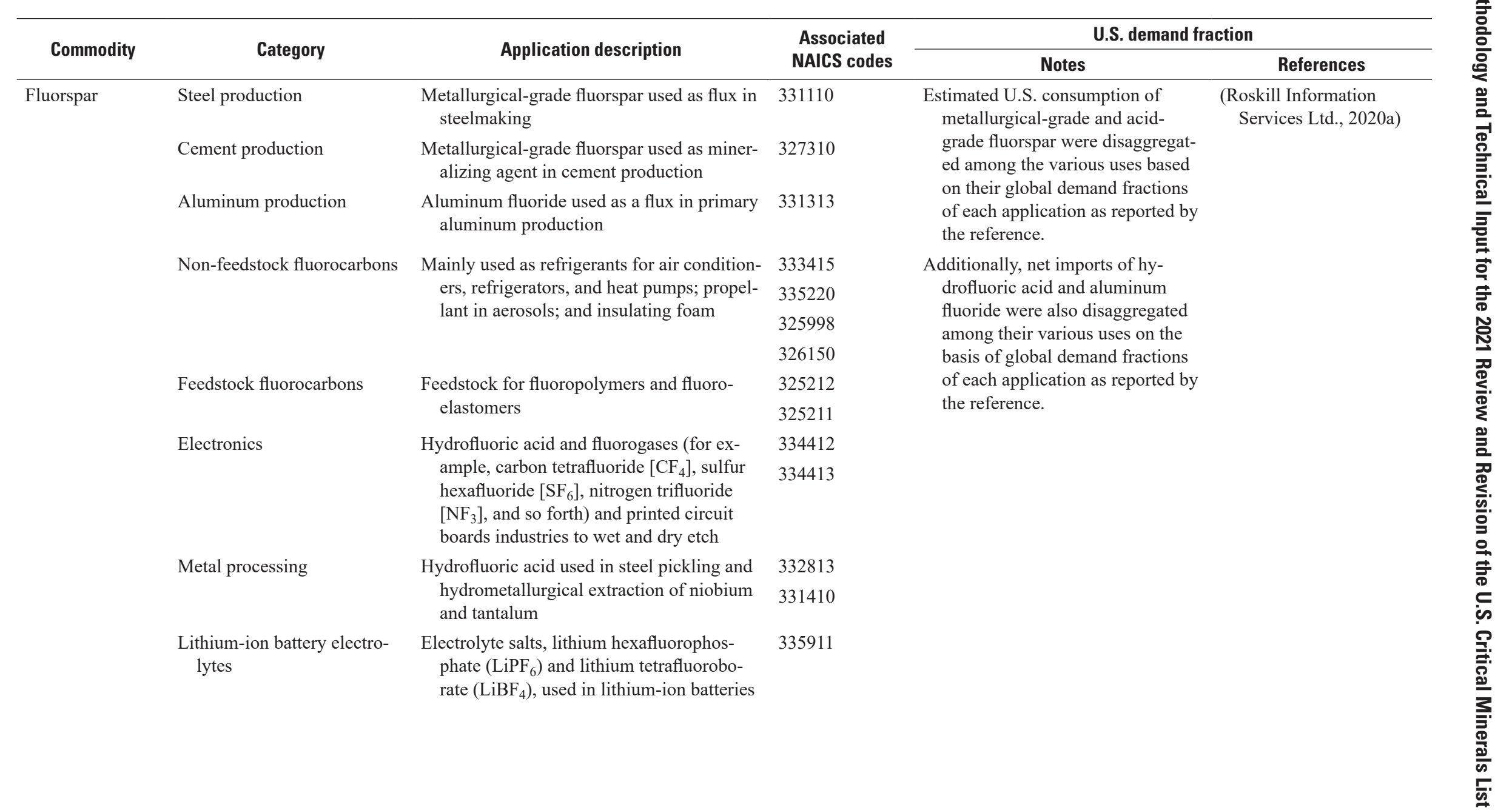


Table 1.3. Description of applications, associated NAICS codes, and U.S. demand fraction for each newly evaluated commodity—Fluorspar and graphite (2007-2018) and hafnium (2014-2018).-Continued

[NAICS, North American Industry Classification System]

\begin{tabular}{|c|c|c|c|c|c|}
\hline \multirow{2}{*}{ Commodity } & \multirow{2}{*}{ Category } & \multirow{2}{*}{ Application description } & \multirow{2}{*}{$\begin{array}{l}\text { Associated } \\
\text { NAICS codes }\end{array}$} & \multicolumn{2}{|c|}{ U.S. demand fraction } \\
\hline & & & & Notes & References \\
\hline \multirow{14}{*}{$\begin{array}{l}\text { Fluorspar } \\
\quad \text {-Continued }\end{array}$} & \multirow[t]{14}{*}{ Other applications } & \multirow{14}{*}{$\begin{array}{l}\text { Petroleum alkylation; glassmaking; natural } \\
\text { graphite treatment; toothpastes and } \\
\text { detergents; boron trifluoride as a catalyst } \\
\text { in synthesis of paints, pharmaceuticals, } \\
\text { fibers and filaments; vitamins; weld- } \\
\text { ing rods; inorganic fluoride salts (for } \\
\text { example, potassium fluoride); and sulfuryl } \\
\text { fluoride for fumigation. }\end{array}$} & 324110 & & \\
\hline & & & 325120 & & \\
\hline & & & 325180 & & \\
\hline & & & 325199 & & \\
\hline & & & 325220 & & \\
\hline & & & 325320 & & \\
\hline & & & 325412 & & \\
\hline & & & 325510 & & \\
\hline & & & 325611 & & \\
\hline & & & 327212 & & \\
\hline & & & 327213 & & \\
\hline & & & 327215 & & \\
\hline & & & 333992 & & \\
\hline & & & 335991 & & \\
\hline \multirow{9}{*}{$\begin{array}{c}\text { Graphite (natural } \\
\text { and synthetic) }\end{array}$} & Batteries & Spherical graphite made from small- to & 335911 & \multirow{9}{*}{$\begin{array}{l}\text { Data provided in noted references } \\
\text { were for end-use fractions of } \\
\text { natural and synthetic graphite } \\
\text { in North America for } 2016 \text { and } \\
\text { 2017. Other years were assumed } \\
\text { to have similar end-use fractions. }\end{array}$} & \multirow{9}{*}{$\begin{array}{l}\text { (Roskill Information } \\
\text { Services Ltd., 2017, } \\
\text { 2018a) }\end{array}$} \\
\hline & & $\begin{array}{l}\text { medium-sized flake (or spheroidized } \\
\text { artificial graphite) for the anode of mainly } \\
\text { lithium-ion batteries but also primary } \\
\text { alkaline batteries, lead-acid batteries, and } \\
\text { other battery types }\end{array}$ & 335912 & & \\
\hline & Electrodes & $\begin{array}{l}\text { Primary synthetic graphite used in the manu- } \\
\text { facturing of electrodes used in steelmak- } \\
\text { ing (for example, electric arc finance) and } \\
\text { ferroalloy manufacturing }\end{array}$ & 331110 & & \\
\hline & \multirow[t]{6}{*}{ Foundries } & \multirow{6}{*}{$\begin{array}{l}\text { Additive to foundry facing sand, as a mound } \\
\text { wash lubricant, and as permanent mound } \\
\text { material for ferrous and nonferrous metal } \\
\text { casting }\end{array}$} & 331511 & & \\
\hline & & & 331512 & & \\
\hline & & & 331513 & & \\
\hline & & & 331523 & & \\
\hline & & & 331524 & & \\
\hline & & & 331529 & & \\
\hline
\end{tabular}


Table 1.3. Description of applications, associated NAICS codes, and U.S. demand fraction for each newly evaluated commodity-Fluorspar and graphite (2007-2018) and hafnium (2014-2018).-Continued

[NAICS, North American Industry Classification System]

\begin{tabular}{|c|c|c|c|c|c|}
\hline \multirow{2}{*}{ Commodity } & \multirow{2}{*}{ Category } & \multirow{2}{*}{ Application description } & \multirow{2}{*}{$\begin{array}{l}\text { Associated } \\
\text { NAICS codes }\end{array}$} & \multicolumn{2}{|c|}{ U.S. demand fraction } \\
\hline & & & & Notes & References \\
\hline \multirow[t]{26}{*}{$\begin{array}{l}\text { Graphite (natural } \\
\text { and synthetic) } \\
\text { - Continued }\end{array}$} & Friction materials & $\begin{array}{l}\text { Friction lining brake pads, drums, and } \\
\text { clutches to improve friction coefficient for } \\
\text { braking comfort and noise reduction }\end{array}$ & 336340 & & \\
\hline & Graphite shapes & Synthetic graphite used for aerospace & 336413 & & \\
\hline & & components (rocket nozzles, nose cones, & 336419 & & \\
\hline & & $\begin{array}{l}\text { structural components); production of } \\
\text { polysilicon used in solar cells; chemical }\end{array}$ & 327992 & & \\
\hline & & processing equipment; bearings; glass & 332410 & & \\
\hline & & production; furnace parts & 332911 & & \\
\hline & & & 333249 & & \\
\hline & & & 332420 & & \\
\hline & & & 333242 & & \\
\hline & & & 332991 & & \\
\hline & & & 327211 & & \\
\hline & & & 327212 & & \\
\hline & & & 327213 & & \\
\hline & & & 327215 & & \\
\hline & & & 333994 & & \\
\hline & Lubricants & Various graphite lubricants used as an addi- & 339991 & & \\
\hline & & tive to oil and grease, machinery lubrica- & 332992 & & \\
\hline & & $\begin{array}{l}\text { tion, metalworking and forging fluids, } \\
\text { flange grease for railways }\end{array}$ & 325320 & & \\
\hline & & & 332111 & & \\
\hline & & & 332112 & & \\
\hline & Refractories & $\begin{array}{l}\text { Large-sized flake graphite used in the } \\
\text { production of iron and steel production, as } \\
\text { well as nonferrous metals, and nonmetal- } \\
\text { lic minerals. }\end{array}$ & 327120 & & \\
\hline & Other applications & Flexible graphite (for example, gaskets, & 325998 & & \\
\hline & & vales, seals); flame retardants; conductive & 325510 & & \\
\hline & & polymers; powder metallurgy; nuclear ap- & 327999 & & \\
\hline & & fuel assembly); pencils; fuel cells; foam; & 334613 & & \\
\hline & & paint; synthetic diamonds & 339940 & & \\
\hline
\end{tabular}


Table 1.3. Description of applications, associated NAICS codes, and U.S. demand fraction for each newly evaluated commodity-Fluorspar and graphite (2007-2018) and hafnium (2014-2018).-Continued

[NAICS, North American Industry Classification System]

\begin{tabular}{|c|c|c|c|c|c|}
\hline \multirow{2}{*}{ Commodity } & \multirow{2}{*}{ Category } & \multirow{2}{*}{ Application description } & \multirow{2}{*}{$\begin{array}{l}\text { Associated } \\
\text { NAICS codes }\end{array}$} & \multicolumn{2}{|c|}{ U.S. demand fraction } \\
\hline & & & & Notes & References \\
\hline \multirow[t]{12}{*}{ Hafnium } & \multirow[t]{2}{*}{ Catalysts } & \multirow{2}{*}{$\begin{array}{l}\text { Catalysts used in the production of thermo- } \\
\text { plastics }\end{array}$} & 325211 & \multirow{12}{*}{$\begin{array}{l}\text { Demand fractions were based on } \\
\text { global estimates for 2014-2016. } \\
\text { Estimates for } 2016 \text { were also used } \\
\text { for } 2017 \text { and } 2018 \text {. }\end{array}$} & \multirow{12}{*}{$\begin{array}{l}\text { (Petra Capital Pty Ltd., } \\
\text { 2015; Alkane Resources } \\
\text { Ltd., 2017a, b) }\end{array}$} \\
\hline & & & 325180 & & \\
\hline & Nuclear control rods & Control rods for nuclear reactors & 332410 & & \\
\hline & \multirow[t]{2}{*}{ Optical applications } & \multirow{2}{*}{$\begin{array}{l}\text { Hafnium oxide for surface coating of optical } \\
\text { fibers and dielectric mirrors }\end{array}$} & 333314 & & \\
\hline & & & 335921 & & \\
\hline & Plasma cutting tips & $\begin{array}{l}\text { Inserts for plasma cutting tips and welding } \\
\text { torches }\end{array}$ & 333992 & & \\
\hline & Semiconductors & $\begin{array}{l}\text { Sputtering targets for chemical vapor depo- } \\
\text { sition (CVD) }\end{array}$ & 334413 & & \\
\hline & \multirow[t]{5}{*}{ Superalloys } & \multirow{5}{*}{$\begin{array}{l}\text { Alloying element in superalloys used in } \\
\text { aerospace industrial gas turbines, and } \\
\text { rocket engine nozzles }\end{array}$} & 331492 & & \\
\hline & & & 332117 & & \\
\hline & & & 333611 & & \\
\hline & & & 336412 & & \\
\hline & & & 336415 & & \\
\hline
\end{tabular}




\section{References Cited}

ACRON Group, 2018, Annual report 2017: ACRON Group, 168 p., accessed April 9, 2021, at https://www.acron.ru/ upload/iblock/178/6982_acron_ar17_eng_online 04 may.pdf.

Alkane Resources Ltd., 2017a, Hafnium is essential to aerospace superalloys \& microchips: Alkane Resources Ltd. fact sheet, 2 p., accessed April 9, 2021, at https:/www.alkane.com.au/wp-content/uploads/2017/09/ Hafnium.pdf.

Alkane Resources Ltd., 2017b, High k sourcing \& the supply chain for hafnium and zirconium, in CMC Conference 2017-Critical Materials for Semiconductor Device Manufacturing, Richardson, Tex., May 11-17, 2017, Presentation: Perth, Australia, Alkane Resources Ltd., 31 p.

Darton Commodities Ltd., 2008-2020, Cobalt market review (2008-2020): Guildford, Surrey, United Kingdom, Darton Commodities Ltd., variously paged.

Hedrick, J.B., Sinha, S.P., and Kosynkin, V.D., 1997, Loparite, a rare-earth ore $(\mathrm{Ce}, \mathrm{Na}, \mathrm{Sr}, \mathrm{Ca})\left(\mathrm{Ti}, \mathrm{Nb}, \mathrm{Ta}, \mathrm{Fe}^{+3}\right)$ $\mathrm{O}_{3}$ : Journal of Alloys and Compounds, v. 250, no. 1-2, p. 467-470, accessed April 9, 2021, at https://doi.org/ 10.1016/S0925-8388(96)02824-1.

JSC Solikamsk Magnesium Works, 2019, Annual report 2018: JSC Solikamsk Magnesium Works, 38 p., accessed April 9, 2021, at http://xn--g1ajo.xn--p1ai/raport/2019/ 9600.pdf.

Lynas Corporation Ltd., 2012, Increase in Mt Weld resource estimate for the Central Lanthanide deposit and Duncan deposit: Sydney, Australia, Lynas Corporation Ltd. news release, January 18, 2012, 5 p., accessed April 9, 2021, at https://ynasrareearths.com/wp-content/uploads/2019/05/ Increase_in_Mt_Weld_Resource_Estimate_1068363.pdf.

Lynas Corporation Ltd., 2013-2020, Quarterly reports 2013-2020: Lynas Corporation Ltd., accessed April 9, 2021, at https://www.lynascorp.com/investors-media/ reporting-centre/.

Molycorp Inc., 2015, Form 10 K-[2014]: U.S. Securities and Exchange Commission, accessed April 9, 2021, at https://sec.report/Document/0001489137-15-000007/.

Nassar, N.T., Brainard, J., Gulley, A., Manley, R., Matos, G., Lederer, G., Bird, L.R., Pineault, D., Alonso, E., Gambogi, J., and Fortier, S.M., 2020, Evaluating the mineral commodity supply risk of the U.S. manufacturing sector: Science Advances, v. 6, no. 8, article eaay8647, accessed April 9, 2021, at https://doi.org/10.1126/sciadv.aay8647.
Petra Capital Pty Ltd., 2015, Alkane Resources Limited-An emerging strategic metals business: Sydney, Australia, Petra Capital Pty Ltd., 35 p.

Roskill Information Services Ltd., 2017, Natural and synthetic graphite - Global industry, markets and outlook to 2026 (10th ed.): London, United Kingdom, Roskill Information Services Ltd., 475 p.

Roskill Information Services Ltd., 2018a, Natural and synthetic graphite - Global industry, markets and outlook, 2018 (11th ed.): London, United Kingdom, Roskill Information Services Ltd., accessed April 9, 2021, at https://www.roskillinteractive.com/reportaction/ NGR11/Toc.

Roskill Information Services Ltd., 2018b, Rare earths - Global industry, markets and outlook to 2028 (18th ed.): London, United Kingdom, Roskill Information Services Ltd., accessed April 9, 2021, at https://www.roskillinteractive.com/reportaction/ REY18/Toc.

Roskill Information Services Ltd., 2019a, Lithium-Outlook to 2028 (16th ed.): London, United Kingdom, Roskill Information Services Ltd., accessed April 9, 2021, at https://www.roskillinteractive.com/reportaction/LIT16/Toc.

Roskill Information Services Ltd., 2019b, Rare earthsOutlook to 2029 (19th ed.): London, United Kingdom, Roskill Information Services Ltd., accessed April 9, 2021, at https://www.roskillinteractive.com/reportaction/ REY19/Toc.

Roskill Information Services Ltd., 2020a, Fluorspar-Outlook to 2029 (14th ed.): London, United Kingdom, Roskill Information Services Ltd., accessed April 9, 2021, at https://www.roskillinteractive.com/reportaction/FLU14/Toc.

Roskill Information Services Ltd., 2020b, Magnesium metalOutlook to 2030 (13th ed.): London, United Kingdom, Roskill Information Services Ltd., accessed April 9, 2021, at https://www.roskillinteractive.com/reportaction/ MGM13/Toc.

Toyota Tsusho Corp., 2015, Toyota Tsusho inks rare earths contract with Indian state corporation-Rare earth oxides produced in Indian to be exported to Japan, Europe and Americas: Toyota Tsusho Corp. press release, December 10, 2015, accessed April 9, 2021, at https://www.toyota-tsusho.com/english/press/detail/ 151210_002928.html.

U.S. Census Bureau, 2018, USA Trade Online: U.S. Census Bureau database, accessed April 9, 2021, at https://usatrade.census.gov/. 
U.S. Department of Defense, 2020, Security of supply: U.S. Department of Defense Office of Industrial Policy website, accessed April 9, 2021, at https://www.businessdefense.gov/security-of-supply/.

U.S. Geological Survey, 2012-2020, Mineral commodity summaries 2012-2020: Reston, Va., U.S. Geological Survey, variously paged.
U.S. Geological Survey, 2020, National Minerals Information Center-Periodic publications-Minerals yearbook (annual): U.S. Geological Survey website, accessed April 9, 2021, at https://www.usgs.gov/centers/nmic/ specialty-items.

Vietnam Rare Earth JSC, 2016, Products details: Vietnam Rare Earth JSC website, accessed April 9, 2021, at http://vtre.vn/ products.html.

World Bureau of Metal Statistics, 2020, World metal statistics yearbook 2020: Ware, United Kingdom, World Bureau of Metal Statistics, 74 p. 
$\frac{1}{19}$

高.

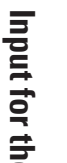

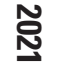

艿.

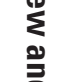

言

空.

음.

o

栉

:

$\frac{3}{3}$

产

क

过

స̃

త్

点 